\title{
RECENT DEVELOPMENTS IN INDIANA FAMILY LAW
}

\author{
AMY E. HIGDON* \\ EMILY J. BARRY** \\ INTRODUCTION
}

This Article surveys the volume of Indiana appellate decisions involving family law topics published from October 1, 2013, through September 30, 2014, as well as a Seventh Circuit Court of Appeals opinion of September 4, 2014. These cases concentrate on the matters of dissolution of marriage; the rights of same-sex couples; child custody, parenting time, and grandparent visitation; child support; and adoption and guardianship. ${ }^{1}$

\section{DisSOLUTION OF MARRIAGE}

The section below reviews noteworthy cases which involved property division in dissolution matters, spousal maintenance determinations, and a guardian's authority to petition for the ward in family law matters.

\section{A. Property Division}

Property division disputes in a dissolution proceeding often arise from fundamental disagreements between the parties, typically with regard to establishing the property to be divided, the valuation of said property to be divided, and the way in which the property will be divided.

1. Crider v. Crider: Defining, Valuing, and Dividing Complex Marital Estates.-In Crider v. Crider, ${ }^{2}$ the Indiana Court of Appeals was presented with

* Partner, Nickloy \& Higdon. B.S., summa cum laude, 1996, Ball State University, Muncie, Indiana; J.D., cum laude, 1999, Indiana University Robert H. McKinney School of Law, Indianapolis, Indiana. Ms. Higdon is a Certified Family Law Specialist as certified by the Indiana Family Law Certification Board and was selected as a Rising Star attorney for 2009, 2010, 2011, 2012, 2013, 2014, and 2015 as rated by Super Lawyers Magazine.

** Associate, Nickloy \& Higdon. B.A., cum laude, 2007, Connecticut College, New London, Connecticut; J.D., 2010, Michigan State University College of Law, East Lansing, Michigan.

1. Family and Juvenile Law in Indiana are derived from title 31 of the Indiana Code. While title 31 refers to Family and Juvenile Law, this Article will focus specifically on the legal issues associated primarily with articles 9 through 21, thereby excluding Child Services and Juvenile Law matters under title 31, articles 25 through 40 . The family law matters addressed herein also are governed by the Indiana Child Support Rules and Guidelines, adopted January 1, 2010, and the Indiana Parenting Time Guidelines, adopted March 1, 2013. Other applicable statutes include sections from the Indiana Probate Code under title 29, namely article 3 on guardianship. Many family law matters implicate additional titles from Indiana Code, including but not limited to title 34 for civil procedure matters, such as contempt actions. See generally IND. CODE § 34-47-1-1. Title 35 will also apply, specifically for criminal procedure issues relating to children and/or spouses.

2. 15 N.E.3d 1042 (Ind. Ct. App.), trans. denied, 20 N.E.3d 852 (Ind. 2014).

http://dx.doi.org/10.18060/4806.0043 
ten issues on appeal. ${ }^{3}$ Due to the depth and breadth of this opinion, it is strongly recommended that practitioners review this decision in its entirety; however, major legal issues presented in the case are outlined herein. These issues include whether the trial court: properly valued and divided closely-held businesses, properly excluded purported loans from husband's father to husband, properly ordered a cash equalization payment with interest and ordered a continuing lien on future property, properly implemented an automatic child support modification, and properly granted an award of stock and membership interests to wife in the event husband failed to timely pay an equalization payment. ${ }^{4}$

Husband and wife married in 1992 and had two children during the marriage, one of whom was emancipated at the time of the court of appeals decision. ${ }^{5}$ Husband co-owned closely-held interests in a variety of business entities which were also co-owned by his father and brother. ${ }^{6}$ Husband's businesses included ten closely held corporations, the most notable of which involved road and other construction. ${ }^{7}$ Ultimately, the business entities ("Crider Entities") intervened after the final decree of dissolution was entered, due to restrictions on stock and share transfers of Crider Entities as required by the trial court's property division order. ${ }^{8}$ Wife, during the course of the marriage, was primarily a stay-at-home mother, had engaged in an unsuccessful interior design business, and had worked part-time. ${ }^{9}$

Husband's finances were complicated, to say the least; however, the parties' lifestyle indicated a high level of income mainly originating from Husband's business ownership interests, although husband presented evidence of a number of outstanding loans from family members, mainly owed to husband's father. ${ }^{10}$ The parties presented significant volumes of primarily disparate testimony from experts regarding the valuations of the businesses and properties, the relevance of unfunded union pension liabilities, the methodology for the appraisal of equipment and machinery, and valuation differences in semi-developed land holdings. ${ }^{11}$

Ultimately, the trial court mainly adopted the values of wife's experts, with the exception of her appraisal of equipment and machinery, and found that the total value of husband's business and real estate interests was over eleven million dollars. ${ }^{12}$ The trial court then split the marital estate equally, with wife receiving nominal liquid assets and husband ordered to make a $\$ 4,752,066$ equalization payment to bear statutory interest in the event he did not pay said sum, in full,

3. Id. at $1046-47$.

4. $I d$.

5. Id. at 1047.

6. Id.

7. Id.

8. Id. at $1047-48,1052$.

9. Id. at 1048 .

10. Id. at $1048-49$.

11. Id. at $1050-52$.

12. Id. 
within ninety days. ${ }^{13}$ The trial court also included two controversial prospective clauses which provided wife an automatic ownership and control interest in half of husband's shares in the Crider Entities in the event husband failed to pay the equalization payment within 180 days from the date of the decree, as well as a reduction in husband's support ninety days after the date of the decree of dissolution. ${ }^{14}$

Husband did not make the equalization payment, and when filing his appeal, did not request a stay of judgment. ${ }^{15}$ Thereafter, wife sought to modify the dissolution decree regarding the automatic reduction in child support, as no equalization payment had been made, thereby mitigating the reasons for the reduction in child support. ${ }^{16}$ While the appeal was pending, the trial court ruled on this motion and modified husband's support obligation. ${ }^{17}$

On review by the court of appeals, the findings of fact and conclusions of law were, for the most part, found to be within the trial court's discretion, specifically the valuations of business entities, the award of interest on the equalization payment, and the failure of the trial court to include loans from husband's father when no payments were ever made from husband to his father. ${ }^{18}$

a. Automatic child support reduction.-The court remanded the issue of an automatic child support reduction to the trial court upon conclusion of the appeal in order to more accurately recalculate the husband's support obligations in light of the post-appeal status of the parties' incomes, which related to husband's equalization payment and wife's failure to receive the same. ${ }^{19}$

Additionally, the court of appeals, sua sponte, addressed the trial court's modification of child support based on a petition presented by wife during the pendency of the appeal, noting that when an appeal is pending, the trial court cannot enter an order materially modifying the decree after it lost jurisdiction to the court of appeals, which was therefore an error on behalf of the trial court. ${ }^{20}$

b. Ownership and division of closely-held enterprises to satisfy equalization payments.- Ownership and control of the Crider Entities was the final significant issue addressed by the court of appeals. This section of the Crider opinion has particular relevance for practitioners with clients who have interests in closelyheld enterprises and the recommended methodologies for division of these enterprises. In Crider, the court indicated that the trial court went too far in granting wife ownership and control in husband's businesses with the automatic security interest provision. ${ }^{21}$ While it was appropriate to grant wife security interests against husband's stock and membership to guarantee payment of the

13. Id. at 1051.

14. Id. at 1052 .

15. Id.

16. Id.

17. Id. at 1053 .

18. Id. at 1053-63.

19. Id. at 1063-65.

20. Id. at 1064-65.

21. Id. at 1070. 
equalization judgment, the trial court's order granting her control entangled the ex-spouses in a family business. ${ }^{22}$ The court suggested a narrower division of husband's shares to affect a more minimal encroachment of wife on husband's business activities, namely, providing wife with a larger award of non-voting shares so that she would be entitled to receive distributions without actually participating in the business affairs of the enterprises. ${ }^{23}$

The second option for providing for wife's interest and securing the equalization payment in light of husband's non-liquid business assets relied on the analysis and recommendations set forth in F.B.I. Farms Inc. v. Moore. ${ }^{24}$ This alternate methodology provided by the court utilizes Indiana Code section 34-55$3-5$, regarding liens upon and sheriff's sales of stock to satisfy a judgment. ${ }^{25}$ Pursuant to this method, the trial court could have ordered a sheriff's sale of the stock in question, subject to Crider Entities shareholders rights as outlined in their shareholder agreements. ${ }^{26}$ The court of appeals finally noted that if wife is awarded non-voting shares, her ownership interest would end upon the satisfaction of her judgment. ${ }^{27}$

In summary, the authors recommend a full review of the Crider decision, as it provides significant guidance for practitioners dealing with valuation methods, options for division of closely-held enterprises, and assessing child support obligations in high-asset dissolutions.

2. Retirement Account Division and Qualified Domestic Relation Orders.During the review period, two major decisions were issued relating to the importance of the language and timeliness of executing a Qualified Domestic Relations Order ("QDRO") when retirement benefits are in play, and a third case addressed the specific valuation of a $401(\mathrm{k})$.

In Pherson v. Lund, ${ }^{28}$ the parties were married in 1979 and divorced in $1991 .^{29}$ Prior to and during the marriage, husband was a railroad employee. ${ }^{30}$ As part of his employment, he was entitled to non-divisible Tier I income security benefits and divisible Tier II retirement benefits. ${ }^{31}$ In the property settlement agreement, wife was awarded fifty percent of husband's Tier II benefits. ${ }^{32}$ Husband continued to work for the railroad for over eighteen years after the dissolution was finalized. ${ }^{33}$ Upon retirement, wife began receiving fifty percent of the total Tier II benefits that accrued during husband's forty-two years of

22. Id. at 1068 .

23. Id. at 1068-69.

24. Id. at 1069 (citing F.B.I. Farms, Inc. v. Moore, 789 N.E.2d 440 (Ind. 2003)).

25. Id.

26. Id. at 1069-71.

27. Id. at 1071.

28. 997 N.E.2d 367 (Ind. Ct. App. 2013).

29. Id. at 368 .

30. Id.

31. Id.

32. Id. at 368-69.

33. Id. at 369 . 
employment, as opposed to fifty percent of the Tier II benefits that accrued during the marriage. ${ }^{34}$

Husband then filed a motion seeking clarification on the agreement and wife sought dismissal of husband's motion, citing that the division of retirement accounts was a property disposition issue and could not be modified. ${ }^{35}$ After a hearing and inviting post-hearing written submissions, the trial court entered an order specifying that the additional 18.5 years of husband's employment benefits "had not been earned and did not exist at the time of final separation" and were, therefore, not a divisible marital asset. ${ }^{36}$ Wife filed a motion to correct error, which resulted in the trial court correcting a typographical error and applying a coverture fraction. ${ }^{37}$

On appeal, the court of appeals applied Indiana Code section 31-15-2-17(c), stating, "[t]he disposition of property settled by an agreement described in subsection (a) and incorporated and merged into the decree is not subject to subsequent modification by the court, except as the agreement prescribes or the parties subsequently consent." 38 Further, under Indiana Code section 31-15-79.1(a) "property disposition ... may not be revoked or modified, except in case of fraud." $"$ As such, the trial court may not modify a property settlement agreement or order; however, the court may resolve a dispute over the interpretation of the settlement agreement or property division order. ${ }^{40}$

In this instance, the property in question related to a right to receive vested retirement benefits which were payable after the dissolution; however, such property did not include post-dissolution employer contributions to a retirement fund. ${ }^{41}$ The court of appeals agreed that the trial court acted within its discretion, as the value of the Tier II benefits were unknown at the time of the dissolution because of ongoing contributions of husband's post-dissolution employment efforts. ${ }^{42}$ As such, the court of appeals found the parties' agreement simply failed to assign a monetary value for the vested pension as it could not undertake the valuation of the asset at the time of the dissolution and this valuation subsequently was the trial court's responsibility to undertake. ${ }^{43}$

In Ryan v. Janovsky, ${ }^{44}$ the court of appeals was presented with the issue of whether securing a Qualified Domestic Relations Order ("QDRO") was time barred by the statute of limitations and the equitable doctrines of laches and

34. Id.

35. Id.

36. Id (quoting app. at 17).

37. Id.

38. Id. (quoting IND. CODE $\S 31-15-2-17$ (c) (2015)).

39. Id. (quoting IND. CODE $\S 31-15-7-9.1$ (a) (2015)).

40. Id. (citing Shorter v. Shorter, 851 N.E.2d 378, 383 (Ind. Ct. App. 2006)).

41. Id. at 370 (citing IND. CODE $\S 31-15-7-4$ (a) (2015)).

42. Id. at 370-71.

43. Id. at 371 .

44. 999 N.E.2d 895 (Ind. Ct. App. 2013), trans. denied, 7 N.E.3d 993 (Ind. 2014). 
waiver. ${ }^{45}$ The parties were married in 1974 and divorced in $1991 .{ }^{46}$ Pursuant to the parties' property settlement, wife was to receive, via a QDRO, one-half of husband's pension as of December 1, 1991. ${ }^{47}$ Finally, in 2012, wife's counsel prepared and forwarded the QDRO to husband for his signature. ${ }^{48}$ Husband refused to sign. ${ }^{49}$ Wife then brought a Petition for Rule to Show Cause alleging husband's willful disregard of the agreement in his refusal to sign the QDRO. ${ }^{50}$ Husband alleged that there was no legal basis for him to execute a QDRO over twenty years after the decree of dissolution. ${ }^{51}$ The trial court found that wife was not entitled to any portion of husband's pension based on the inordinate amount of time she waited to perfect her interest in husband's pension. ${ }^{52}$

The court of appeals analyzed the parties' arguments as to the timeliness of the QDRO, emphasizing that the QDRO "creates or recognizes the existence of an alternate payee's right to pension benefits." 53 Although concern was articulated for the inordinate delay in submitting the QDRO, the court held that this delay did not cause forfeiture of wife's right to her portion of the pension benefits under the parties' settlement agreement. ${ }^{54}$ The court also disagreed with husband's arguments under Needham v. Suess ${ }^{55}$ and Indiana Code section 34-11$2-12,{ }^{56}$ stating that husband's citations referenced judgment liens and enforcement of liens on property. ${ }^{57}$ Additionally, husband had not yet received any distributions from the pension and, any applicable statute of limitations would not begin to run until the first distribution was made, at the earliest. ${ }^{58}$ The court emphasized that the act of the trial court dividing the pension plan is not complete, and therefore not enforceable under ERISA until such time as the plan administrator has approved the QDRO and divided the account accordingly. ${ }^{59}$

The fact that husband was not receiving distributions was relevant in the court of appeals' opinion, as the panel disagreed with his argument for equitable doctrines of laches and waiver because husband would not be prejudiced by executing the QDRO even twenty years after the dissolution. ${ }^{60}$ Ultimately,

\section{Id. at 897 .}

46. $I d$.

47. Id.

48. Id.

49. Id.

50. Id.

51. Id.

52. Id. at 897-98.

53. Id. at 898 (quoting Hogle v. Hogle, 732 N.E.2d 1278, 1280 n.3 (Ind. Ct. App. 2000), trans. denied, 753 N.E.2d 9 (Ind. 2001)).

54. Id. at 898-99.

55. 577 N.E.2d 965 (Ind. Ct. App. 1991).

56. IND. CODE § 34-11-2-12 (2015).

57. Ryan, 999 N.E.2d, at 899-900.

58. $I d$.

59. Id. at 900 (citing Jordan v. Jordan, 147 S.W.3d 255 (Tenn. Ct. App. 2004)).

60. Id. 
because the trial court's order denied wife's right to her portion of husband's pension and resulted in a windfall for husband, the court concluded that the trial court's order was an abuse of discretion.$^{61}$ Further, the court clarified that even if husband began to receive payments from his pension, wife would be entitled to payments directly from husband, as opposed to husband's employer. ${ }^{62}$

Although the Ryan case leaves the window open for an extended preparation and presentation of QDROs after a divorce, ${ }^{63}$ given the court of appeals' echoes of the trial court's frustration with the inordinate amount of time which wife waited to execute said QDRO, it is advisable to include deadlines and instructions on preparation of QDROs in dissolution settlements.

Finally, in Pitcavage v. Pitcavage ${ }^{64}$ the Indiana Court of Appeals found the trial court abused its discretion when it valued wife's 401(k) account at $\$ 10,424.99$, the amount contributed during the marriage, instead of using the proper valuation of the $401(\mathrm{k})$ account at $\$ 56,820.36$, which properly reflected the sum of the funds in the account as of the date of filing. ${ }^{65}$ In light of the trial court's error in valuing this marital asset, this issue alone was reversed and remanded with instructions. ${ }^{66}$

3. Vested Interests in Life Estates. - The Indiana Court of Appeals dealt with the improper exclusion of a vested property interest, namely a joint tenancy subject to a life estate, in the matter of Falatovics $v$. Falatovics. ${ }^{67}$ The parties were married in 1989 and, in 2005, husband's parents conveyed two parcels of real estate by quitclaim deed to husband and husband's brother as joint tenants with rights of survivorship, subject to the life estate of husband's parents. ${ }^{68}$ Although the parties agreed on the value of these properties, husband's mother maintained possession of the properties at trial. ${ }^{69}$ The trial court excluded these properties from the marital estate because "[h] usband will never possess this land if he predeceases his mother; or if he predeceases his brother [and he has not] invested any money, labor, or time into the real estate." ${ }^{.70}$ Wife subsequently appealed. ${ }^{71}$

Indiana operates on a "one pot theory," meaning all marital property goes into the singular marital pot for division, whether it is owned by either spouse before the marriage, acquired by either spouse after the marriage and before the final separation of the parties, or acquired by their joint efforts. ${ }^{72}$ Citing Moyars

\author{
61. Id. \\ 62. Id. \\ 63. Id. \\ 64. 11 N.E.3d 547 (Ind. Ct. App. 2014), reh'g denied. \\ 65. Id. at 568 . \\ 66. Id. at 569-70. \\ 67. 15 N.E.3d 108 (Ind. Ct. App. 2014). \\ 68. Id. at 109 . \\ 69. Id. at 109-10. \\ 70. $I d$. at 110 (alteration in original). \\ 71. Id at 109 . \\ 72. IND. CODE $\S 31-15-7-4$ (a) (2015).
}


v. Moyars ${ }^{73}$ the court agreed with wife that husband had a remainder interest in the parcels, which represents a present pecuniary interest with a corresponding value. $^{74}$ As the value of these properties was improperly excluded, the court reversed the trial court's decision on the valuation of the marital estate and remanded the division of the marital estate for reconsideration upon inclusion of all marital property. ${ }^{75}$

4. Division of Lottery Winnings after Extended Separation.-In In re Marriage of Perez ${ }^{76}$ the court of appeals held that the trial court did not abuse its discretion in awarding wife only $2.5 \%$ of husband's lottery winnings, which were obtained during the marriage, but after the parties had been separated over five years. ${ }^{77}$ Although the parties were married in 2002, they separated in 2006 and over the next six years never comingled assets, used separate bank accounts, and lived as single adults. ${ }^{78}$ Husband won two million dollars from the Hoosier Lottery in January 2011, and filed for divorce in March 2011. ${ }^{79}$

Although wife served husband with Requests for Admissions regarding property division, the ultimate division of the lottery winnings was clearly within the discretion of the trial court. ${ }^{80}$ The court of appeals provided guidance on the scope of requests for admissions, indicating that requests for admissions can establish legal conclusions. ${ }^{81}$ Here, husband failed to respond to requests for admission, one of which thereby admitted that a 70/30 division of the marital estate, with wife receiving the seventy percent share, would be a fair and equitable division of assets. ${ }^{82}$ However, the language in wife's requests for admissions did not conclusively establish that this proposed division was the only fair and equitable division of the marital estate, and thereby left the trial court with the authority to determine a fair and equitable distribution of the marital estate. $^{83}$

\section{B. Spousal Maintenance}

Indiana appellate courts addressed a number of spousal maintenance issues during the survey period relevant to family law practitioners. The principle focus of these cases concerned the issues of maintenance stipulations between parties, the modification of certain maintenance agreements, and the timeliness for a

73. 717 N.E.2d 976 (Ind. Ct. App. 1999), trans. denied, 735 N.E.2d 225 (Ind. 2000).

74. Falatovics, 15 N.E.3d at 111.

75. Id. at 111-12.

76. 7 N.E.3d 1009 (Ind. Ct. App. 2014).

77. Id. at 1010 .

78. Id.

79. Id.

80. Id. at 1011 .

81. Id. (citing Gen. Motors Corp., Chevrolet Motors Div. v. Aetna Cas. \& Sur. Co., 573 N.E.2d 885, 888 (Ind. 1991)).

82. Id.

83. Id. 
maintenance determination.

1. Stipulations on Incapacity and Inability to Support.-When the parties stipulate to a spouse's incapacity, this stipulation is binding on both the parties and the trial court, which thereby establishes a particular matter as fact. ${ }^{84}$ If denying an award of incapacity maintenance after such a stipulation, the trial court must specifically identify extenuating circumstances directly related to the statutory criteria for awarding the maintenance which justify the denial of the award..$^{85}$

In Coleman v. Atchison, the Indiana Court of Appeals considered whether the trial court abused its discretion in denying wife's request for incapacity maintenance and whether the trial court abused its discretion in its division of the marital estate. ${ }^{86}$ The legal issues presented as to spousal maintenance are addressed herein.

The parties married in 2000, had no children together, and wife filed her petition for dissolution in January 2011. ${ }^{87}$ Beginning in 2006, wife received social security disability payments while husband continued to maintain relatively regular employment. ${ }^{88}$ The economic circumstances of the parties during the marriage were noted in the trial court's findings, namely that the parties had a very low standard of living during the marriage, and that husband frequently endured furloughed employment due to the nature of his job. ${ }^{89}$

The trial court also analyzed the economic circumstances of the parties at the time of the dissolution, noting that wife resided with her two adult daughters in the marital residence, was able to purchase a new car, and was able to pay all monthly bills. ${ }^{90}$ Husband, on the other hand, declared bankruptcy, lost his home, and was residing in a trailer with his unemployed fiancée and his teenage son. ${ }^{91}$ The parties stipulated to the wife's disability and the trial court ruled that husband should not pay wife incapacity maintenance. ${ }^{92}$ The trial court articulated that incapacity maintenance is not mandatory and that wife should not be awarded incapacity maintenance based on language from Temple $v$. Temple. ${ }^{93}$

The court of appeals found that the trial court erred in issuing a finding for spousal maintenance yet not making an award for the same. ${ }^{94}$ The deficit of the trial court's order was the inconsistency in conclusions to both grant and deny incapacity maintenance. ${ }^{95}$ As such, the court found clear error as to the issue of

84. Coleman v. Atchison, 9 N.E.3d 224, 229 (Ind. Ct. App. 2014).

85. Id. at 228-29 (citing Cannon v. Cannon, 758 N.E.2d 524, 527 (Ind. 2001)).

86. Id. at 225 .

87. Id.

88. Id.

89. Id. at 226-27.

90. Id.

91. Id.

92. Id.

93. Id. at 226, 229 (citing Temple v. Temple, 328 N.E.2d 227, 230 (Ind. Ct. App. 1975)).

94. Id. at 229 .

95. Id. 
incapacity maintenance and remanded the matter with specific instructions for the trial court to either award wife incapacity maintenance or to articulate specific extenuating circumstances relating to the statutory criteria justifying a denial of the award. ${ }^{96}$

2. Agreements Including Language on Modification of Incapacity Maintenance.-The Indiana Supreme Court addressed whether a court may modify a maintenance obligation originating from a settlement agreement between the parties in Pohl v. Pohl. ${ }^{97}$ Here, the Court analyzed the competing interests of upsetting a balanced settlement struck by the parties during negotiations with the objective of finality versus the potential undue hardship for a party when he or she encounters unforeseen circumstances ${ }^{98}$ Ultimately, given the language outlined in the parties' stipulation on maintenance, the Court held that an agreement regarding incapacity maintenance is modifiable if so agreed upon, in writing, by the parties. ${ }^{99}$

The parties married in 1991 and had one child in $1995 .{ }^{100}$ Husband received Social Security Disability Income in 1996, and wife, for a large portion of the marriage, was the breadwinner. ${ }^{101}$ The parties' divorce decree and "Custody, Support, and Property Settlement Agreement" ("Agreement") were granted in March 2009, and the parties subsequently filed an Addendum to their Agreement in May 2009. ${ }^{102}$ The language of the Addendum was written by husband's counsel as follows:

[T] he parties herein stipulate and agree that the Wife shall pay to the Husband the sum of Four Thousand Dollars $(\$ 4,000.00)$ per month as post-dissolution spousal maintenance, commencing the 5th day of June, 2013, and continuing on the 5th day of each successive month thereafter until further order of the court or agreement of the parties. ${ }^{103}$

An attorney represented husband in the execution of this Addendum while wife was self-represented. ${ }^{104}$ Almost ten months before her first maintenance payment was set to come due, wife filed a petition to modify and reduce the maintenance obligation to $\$ 1000$, citing a change in husband's circumstances. ${ }^{105}$ After a hearing, the trial court denied wife's petition, finding that the Addendum could not be modified absent a finding of fraud, duress, or mistake, and wife appealed. ${ }^{106}$ The Indiana Supreme Court granted transfer to resolve the question

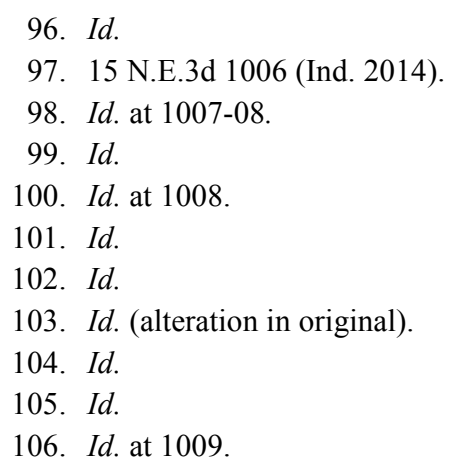


left open by Voight v. Voight. ${ }^{107}$

In its analysis, the court considered the authority to modify the agreed maintenance Addendum when a court, on its own, could have imposed the obligation absent the parties' agreement. ${ }^{108}$ Noting the ambiguity in the language of the Addendum, the court found, through competent extrinsic evidence, that the type of maintenance contemplated between the parties was, in fact, incapacity maintenance. ${ }^{109}$

Husband argued that the provision was not modifiable as a trial court could not have issued an identical award granting maintenance at a future date; however, the Indiana Supreme Court read the addendum language to both establish husband's right to the maintenance as well as his right to waive his collection of maintenance sums until a later date. ${ }^{110}$ Also important to note, the Addendum language spoke for itself in allowing for future modification, despite language in the parties' settlement which provided a mutual release of legal obligations between the spouses. ${ }^{111}$ The court carefully analyzed the implications of expanding a court's role when modifying previous agreements which were made through the parties' freedom to contract and negotiate, which would then compete with the interests of parties who find themselves in unforeseen circumstances after an agreement is tendered to and approved by the court. ${ }^{112}$

Ultimately, the Indiana Supreme Court instructed that "when a court could have unilaterally ordered an identical maintenance award, [courts] will presume the parties intended their agreement to be final and non-modifiable unless they specifically provided otherwise." "113 Therefore, the language of the Addendum, which specifically provides for a further court order or agreement by the parties, governs the ability of the Addendum to be modified, and the standard to be applied for modification of a maintenance provision was a substantial and continuing change in circumstances under Indiana Code section 31-15-7-3(1). ${ }^{114}$

3. Maintenance Determinations to Be Entered at the Time of Dissolution.-Family law practitioners must present any and all evidence relevant to a maintenance claim during a dissolution of marriage trial; or in the alternative, that the dissolution issues be bifurcated and a divorce decree held until such time that sufficient evidence can be presented. Lesley v. Lesley $y^{115}$ involved a dissolution of marriage case in which the trial court issued an order in May 2011 that wife did not present sufficient evidence to warrant an award of spousal maintenance. ${ }^{116}$ The trial court, however, indicated that it would

107. See 670 N.E.2d 1270, 1280 (Ind. 1996).

108. Pohl, 15 N.E.3d at 1009 (citing Voight, 670 N.E.2d at 1280).

109. Id. at 1011-12.

110. Id. at 1012 .

111. Id.

112. Id at 1012-13.

113. Id. at 1014 .

114. Id. at 1014-15.

115. 6 N.E.3d 963 (Ind. Ct. App. 2014).

116. Id. at 964 . 
reevaluate the matter if the Social Security Administration ("SSA") determined she was disabled, which the SSA did in November 2011. ${ }^{117}$ The SSA determined that wife was disabled from October 26, 2009, to November 21, 2011; however, the SSA also recommended a disability review in two years, as wife was expected to improve with proper treatment of her medical conditions. ${ }^{118}$

Wife, almost six months later, filed her petition for retroactive maintenance in May 2012. ${ }^{119}$ After a hearing in December 2012, the trial court issued an order in January 2013 awarding wife rehabilitative maintenance from the commencement of the dissolution on May 6, 2011, through November 15, 2012. ${ }^{120}$ Wife filed a motion to correct error and subsequently appealed. ${ }^{121}$ Husband cross-appealed, stating that the trial court did not have statutory authority to hear the issue of spousal maintenance after the issuance of the decree of dissolution of marriage. ${ }^{122}$

The Indiana Court of Appeals relied on statutory interpretation, namely the language of Indiana Code section 31-15-7-1, which provides that the "court may order maintenance in final dissolution of marriage decrees entered under IC 3115-2-16." "123 The Indiana Code offers three limited means for post-dissolution maintenance: spousal incapacity maintenance, caregiver maintenance, and rehabilitative maintenance. ${ }^{124}$ The court reviewed the interplay between Indiana Code section 31-15-7-2, pertaining to awards of spousal maintenance, and Indiana Code section 31-15-7-3, regarding a modification or revocation of spousal maintenance. ${ }^{125}$ In Lesley, the trial court did not find sufficient evidence at the time of the dissolution to establish an award of spousal maintenance for wife, and therefore, the trial court did not have the authority to modify its determination on spousal maintenance. ${ }^{126}$ Accordingly, the issue of spousal maintenance was reversed and the matter was remanded for further proceedings which could include necessary recalculations. ${ }^{127}$

\section{Guardian Authority to File for Divorce}

Prior to July 1, 2014, adults subject to a guardianship were unable to file for divorce. Under Indiana Code section 29-3-9-12.2, an individual who is the subject of a guardianship may now have his or her guardian petition for

117. Id. at 965 .

118. Id.

119. $I d$.

120. Id. at 965-66.

121. Id. at 966 .

122. Id.

123. Id. (quoting IND. CODE $\S 31-15-7-1(2015)$ ) (emphasis in original).

124. Id. at 966-67 (citing Dewbrew v. Dewbrew, 849 N.E.2d 636, 644 (Ind. App. 2006)).

125. Id. at 967-68.

126. Id. at 968 .

127. Id. 
dissolution of marriage, legal separation, or annulment on his or her behalf. ${ }^{128}$ In order to proceed with the filing of such an action, the guardian must first make a determination that the legal action is in the protected person's best interests and thereafter must petition the court for the authority to petition for a dissolution, legal separation, or annulment on behalf of the protected person. ${ }^{29}$ The Indiana Court of Appeals issued a decision during the survey period, prior to the change in Indiana Code section 29-3-9-12.2, articulating this previous legal conundrum in McGee v. McGee. ${ }^{130}$ However, with the changes made by the amendments to Indiana Code section 29-3-9-12.2, Indiana case law may need to address the intricacies and added complications of a guardian filing for dissolution of marriage, legal separation, or annulment on behalf of his or her ward.

\section{RightS OF SAME-SEX COUPLES}

\section{A. Same-Sex Marriage}

Any survey regarding the updates in Indiana family law during this survey period would be incomplete without the inclusion of Baskin v. Bogan. ${ }^{131}$ On appeal from the Southern District of Indiana, the Seventh Circuit Court of Appeals addressed whether Indiana's statutory ban on same-sex marriage was lawful. ${ }^{132}$

In its opinion written by Judge Posner, the Seventh Circuit challenged Indiana's alleged rational basis for banning same-sex marriage on equal protection grounds. ${ }^{133}$ Posner wrote that "[d]iscrimination by a state or the federal government against a minority, when based on an immutable characteristic ... . and occurring against an historical background of discrimination against the persons who have that characteristic, makes the discriminatory law or policy constitutionally suspect." ${ }^{34}$ In the case at hand, the court placed the burden on the State of Indiana to show that the classification discriminating against homosexuals served important governmental objectives and that the discriminatory means were substantially related to the achievement of those objectives. ${ }^{135}$

The State failed to meet its burden, as the rationale provided by the State was that "same-sex couples and their children [do not] need marriage because samesex couples [cannot] produce children, intended or unintended"; ${ }^{136}$ however, Posner rejected this rationale stating that children are better off in families with

128. IND. CODE $§ 29-3-9-12.2$ (2015).

129. Id.

130. 998 N.E.2d 270 (Ind. App. 2013).

131. 766 F.3d 648 (7th Cir.), cert. denied, 135 S. Ct. 316 (2014).

132. $I d$. at 653 .

133. Id. at 654-55.

134. Id. at 654 .

135. Id. at 656 (quoting United States v. Virginia, 518 U.S. 515, 524 (1996)).

136. Id. 
married parents, whether biological or adoptive, and therefore the State's discrimination against same-sex couples was irrational. ${ }^{137}$ In light of the court's finding that no rational basis existed, the court's analysis stopped without addressing any issues of heightened scrutiny under due process arguments. ${ }^{138}$

The court continued its analysis finding the harm to the class of individuals, in this case, homosexuals, was the denial of the right to marry. ${ }^{139}$ Judge Posner outlined the importance of the right to marry, not only for the respectability for the couple's relationship sociologically and psychologically, but also for tangible state and federal benefits conferred to married couples. ${ }^{140}$ Citing United States v. Windsor ${ }^{141}$ the court found that Indiana's law harshly denies same-sex couples the rights otherwise awarded to heterosexual couples, thereby placing same-sex couples in an unstable, second-tier position. ${ }^{142}$

Returning to its original focus on the children of same-sex couples, the court cited Windsor again, indicating that laws banning same-sex marriage make it difficult for a child of a same-sex couple to comprehend the integrity and closeness of their own family dynamics in relation to other families. ${ }^{143}$ Judge Posner also specifically outlined the rights conferred upon same-sex couples once married, namely the duties and responsibilities of married life, including obligations which may arise from a divorce. ${ }^{144}$

The State argued that the sole reason for creating legal marriage is to enhance child welfare by channeling procreative sex into a legal context requiring fathers to assume parental responsibility, and as same-sex marriages cannot result in unintended births, the State has no interests in recognizing or protecting the rights of these couples. ${ }^{145}$ The court rejected this argument because marriage in Indiana is not exclusively restricted to only those couples who can produce children. ${ }^{146}$ The court provided the example that a marriage does not become invalid when one spouse becomes infertile due to age or disease. ${ }^{147}$ Further, the court stressed that Indiana's denial of same-sex marriage ignored the fact that same-sex couples are more likely to adopt foster children than opposite sex couples, which, in turn, improves the welfare of children. ${ }^{148}$

Ultimately, the court criticized the State for its oversight in banning same-sex marriage, where allowing the same would actually provide more stability for the welfare of children who are the product of accidental or unmarried births,

137. Id. at 658 .

138. Id. at 656-57.

139. Id. at 657 .

140. Id. at 658-59.

141. 133 S. Ct. 2675 (2013).

142. Baskin, 766 F.3d at 659 (citing Windsor, 133 S. Ct. at 2694).

143. Id. (citing Windsor, $133 \mathrm{~S}$. Ct. at 2694).

144. Id. at 658-59.

145. Id. at 660 .

146. Id. at 661-62.

147. Id. at 661 .

148. Id. at 664 . 
particularly as these birth rates continue to climb in Indiana. ${ }^{149}$ Because the State failed to demonstrate that the discriminatory ban on same-sex marriage was rationally related to any legitimate government interest, the court found the ban to be unconstitutional. ${ }^{150}$

\section{B. Same-Sex Dissolution and Co-Parenting Before Baskin v. Bogan}

The decisions discussed below were issued prior to the Baskin v. Bogan ruling and are included as a review of Indiana's legal rationale on the rights of same-sex couples prior to the Seventh Circuit Court of Appeal's ruling.

1. Visitation of Child With Same-Sex Domestic Partner.-In A.C. v. N.J. ${ }^{151}$ the same-sex domestic partner of biological mother filed a petition for joint custody and visitation of biological mother's child, who was conceived from an anonymous sperm donor. ${ }^{152}$ Partner's petition was denied by the trial court; however, the Indiana Court of Appeals found that Indiana Supreme Court cases, namely King v. S.B. ${ }^{153}$ signaled the potential to expand the class of petitioners with standing to seek third party visitation, such as those similar to the biological mother's partner in this case. ${ }^{154}$ While partner's other issues on appeal were denied, such as partner's request to be recognized as a second parent and partner's request for joint custody, prior to Baskin, A.C. v. N.J. opened the door for, at a minimum, visitation with a child of a same-sex marriage. ${ }^{155}$

2. Same-Sex Dissolution. - In the case of In re Marriage of Davis ${ }^{156}$ the Indiana Court of Appeals held that a legal marriage between husband and wife was not void after husband legally changed his gender from male to female. ${ }^{157}$ The trial court in In re Marriage of Davis ruled that the couple's marriage was void, as Indiana Code section 31-11-1-1, now unconstitutional, only allowed for females to marry males and males to marry females. ${ }^{158}$ The court of appeals reversed this finding, determining that marriage was entered into as a legitimate couple under Indiana law. ${ }^{159}$ Further, the court of appeals established that the trial court's order was flawed, as the couple's marriage produced one child and voiding the marriage would effectively cause Davis to abandon her child, in spite of Davis being the biological and legal father of the child. ${ }^{160}$ Accordingly, the

149. $I d$.

150. $I d$. at 665 .

151. 1 N.E.3d 685 (Ind. Ct. App. 2013).

152. Id. at 687 .

153. King v. S.B., 837 N.E.2d 965 (Ind. 2005).

154. A.C., 1 N.E.3d at $696-97$.

155. $I d$.

156. 1 N.E.3d 184 (Ind. Ct. App. 2013).

157. $I d$. at 185 .

158. IND. CODE $\S 31-11-1-1$ (2015).

159. Davis, 1 N.E.3d at 189.

160. Id. 
trial court's order was reversed and remanded. ${ }^{161}$

\section{Custody, PARENTING Time, AND GRANDPARENT Visitation}

Another predominant area of family law cases relates to matters of child custody, parenting time, and grandparent visitation.

\section{A. Relocation and Modification}

Given the difficult nature of relocation cases and the frequency of these issues on appeal, Indiana appellate courts continue to offer guidance to practitioners on the interplay of the provisions in Indiana Code section 31-17-2.2. While substantial numbers of cases were issued during the survey period, we focus on those cases which provide clarity when dealing with the burden shifting provisions of Indiana Code section 31-17-2.2-5, as a large majority of relocation decisions hinge on the trial court's discretion in weighing the rationale for the relocation and the best-interest factors.

1. Continued Exploration of "Good Faith" and "Legitimate Reason" for Relocation.- In previous cases, Indiana appellate courts intended for the "good faith" and "legitimate reason" of the relocating parent to not be an inordinately high bar, and to include moving to be near family and for financial reasons, including for employment. ${ }^{162}$ However, as more relocation cases come up on appeal, the appellate courts work to create a more definitive standard to establish some bar, versus no bar whatsoever, as indicated in Judge Robb's dissent in Gilbert v. Gilbert. ${ }^{163}$ This case involved parties who divorced in August 2012 after an eleven year marriage which produced two children. ${ }^{164}$ Mother was awarded primary physical custody with father to exercise parenting time Friday through Tuesday on alternating weekends, overnight on alternating Mondays, and alternating weeks during summer breaks. ${ }^{165}$ Until mother filed her Notice of Intent to Relocate in April 2013, the parties continued to live in close proximity to each other and both parents were actively involved in the children's education and extracurricular activities. ${ }^{166}$

In relocation cases, timing of the planned relocation and filing of the notice continues to be relevant in both the trial and appellate court analysis. Here, mother and her fiancé, who also had prior-born children, were expecting a baby in the spring of 2013 and in early 2013 began looking for an adequate home for the growing family. ${ }^{167}$ Mother then selected a newly constructed home in Goshen, thirty miles away from the children's current residence in Albion. ${ }^{168}$

161. Id.

162. T.L. v. J.L., 950 N.E.2d 779, 787-88 (Ind. Ct. App. 2011).

163. 7 N.E.3d 316, 326 (Ind. Ct. App. 2014).

164. Id. at 318 .

165. Id.

166. Id.

167. Id. at 318-19.

168. Id. at 319 . 
Prior to filing her notice, mother entered into two agreements: one to sell the home in Albion and another to purchase the new home in Goshen. ${ }^{169}$ Mother then filed her notice with the court on April 3, 2013, and father filed his objection almost one month later on May 2, 2013, with his Verified Motion for Modification of Custody, Parenting Time, and Child Support and requested a guardian ad litem ("GAL"). ${ }^{170}$ Mother objected to the appointment of a GAL and the trial court denied father's request, citing that a GAL would unreasonably delay the proceedings. ${ }^{171}$ In light of this issue, the authors recommend that a party file a written objection to relocation as soon as possible to minimize any objections to the appointment of experts to assess the complicated circumstances involved in relocation cases. The trial court then issued an order allowing mother to relocate with father's parenting time to remain the same, finding mother's move was made in good faith and for a legitimate reason and father failed to meet his burden of showing the move was not in the best interests of the children. ${ }^{172}$

The court of appeals analyzed the two-prong test provided under Indiana Code section 31-17-2.2-5(c), requiring the relocating parent to prove "that the proposed relocation is made in good faith and for a legitimate reason" 173 and once the relocating parent establishes the same, the burden of proof shifts to the nonrelocating parent who then must demonstrate, per Indiana Code section 31-172.2-5(d), "that the proposed relocation is not in the best interest of the child." 174 Typical legitimate reasons relate to employment opportunities, financial considerations, and proximity to family; however, these are not the only legitimate reasons a court will accept. ${ }^{175}$ Here, the majority approved of mother's rationale of a larger home and better schools for the children, over father's objection that mother's testimony did not provide any evidence that the school district of her new home was any better than the children's current school system. ${ }^{176}$ The court of appeals also affirmed that mother made efforts to alleviate the inconvenience to father in that father worked in Goshen where she was relocating and his two older children, who were not from the marriage, also attended the same school the children would be attending upon her relocation. ${ }^{177}$

Father also argued on appeal that mother's relocation was not in the children's best interests, ${ }^{178}$ citing the impact of relocation on the children's relationship with extended family members and friends as well as the disruption

169. Id.

170. $I d$.

171. Id.

172. Id.

173. IND. CODE $§ 31-17-2.2-5$ (c) (2011).

174. Id. $\S 31-17-2.2-5(\mathrm{~d})$.

175. Gilbert, 7 N.E.3d at 320.

176. Id. at 320-21.

177. Id.

178. See generally IND. CODE $\S 31-17-2-8$ (2015). 
to their current activities. ${ }^{179}$ The court of appeals noted, however, that the record contradicted father's argument as both parties testified that their children adjust well and make friends easily. ${ }^{180}$ Accordingly, mother's relocation was found to be in the children's best interests. ${ }^{181}$

A notable component of the Gilbert decision lies in Judge Robb's dissent, wherein she warns that accepting any and all reasons for relocation on their face does not create any burden of proof for the relocating party, thereby rendering Indiana Code section 31-17-2.2-5(c) meaningless. ${ }^{182}$ Further, she specifically viewed the evidence presented in favor of mother's rationale for relocation distinctly from the majority, stating mother presented no evidence that Goshen schools were, in fact, better for the children, and mother did not indicate that she inquired into building a new home in the children's home town. ${ }^{183}$ Instead, mother found a solution that worked for her and attempted to tailor a good faith and legitimate reason around her choices which was not an objectively legitimate reason. ${ }^{184}$ While a clear definition does not exist as to what constitutes a good faith and legitimate reason, it remains important for parties to demonstrate tangible, child-focused reasons justifying relocation.

2. Applying the Best Interest Factors in Relocation Matters.-The court of appeals analyzed another relocation case in H.H. v. A.A. ${ }^{185}$ which affirmed the trial court's finding that although a proposed relocation to Hawaii by mother was made in good faith and for a legitimate purpose, said relocation was not in the child's best interest. ${ }^{186}$ In that case, the parties' child was born in January 2006, and the parties, who were already separated, then divorced after the child's birth. ${ }^{187}$ Each party subsequently remarried. ${ }^{188}$ Mother filed her first notice of intent to relocate in April 2012, to which father objected, and the trial court denied mother's first request. ${ }^{189}$ Prior to the trial court's first denial of mother's relocation, mother's new husband accepted employment in Hawaii. ${ }^{190}$ Mother then filed a second notice in April 2013 and requested a change of judge. ${ }^{191}$ Father again objected and the trial court again denied mother's request to relocate. ${ }^{192}$

$H . H$. provides a thorough analysis of the factors to be applied when

179. Gilbert, 7 N.E.3d at 322.

180. Id. at 323 .

181. Id.

182. Id. at 326.

183. Id. at 325 .

184. Id. at 326-27.

185. 3 N.E.3d 30 (Ind. Ct. App. 2014).

186. Id. at 32 .

187. Id.

188. Id.

189. Id.

190. Id.

191. Id.

192. Id. at 32-33. 
considering relocation, namely the "distance involved, . . . the hardship and expense involved for the non-relocating parent to exercise parenting time, ..." the feasibility of preserving the parent-child relationship, "whether there is an established pattern" by the relocating parent including the promotion or thwarting of the non-relocating parent's contact with the child, the reasons provided by the relocating parent in favor of the relocation, the reasons provided by the nonrelocating parent in opposing the move, and other best interest factors under Indiana Code section 31-17-2-8. ${ }^{193}$ In weighing these factors and applying the same to the circumstances of the parties and the child, the court of appeals found ample evidence supporting the trial court's decision to deny mother's relocation and finding the same was not in the child's best interests. ${ }^{194}$

An additional case during the survey period which focuses on the second prong of a relocation request includes In re Marriage of Harpenau, ${ }^{195}$ in which the court of appeals affirmed the trial court's determination that, although mother presented a good faith and legitimate reason for relocation, the same was not in the children's best interests and thereby warranted a modification of primary custody to father. ${ }^{196}$ Harpenau provides guidance in analyzing the next step in relocation issues, namely modification of custody when a party decides to relocate even after a determination that the relocation is not in the children's best interests and the relocation thereby created a substantial change in circumstances warranting modification of the existing order or agreement. ${ }^{197}$

3. Using Experts in Custody Modification.-When reviewing a Petition to Modify Custody, the trial court may award a modification upon a showing that there has been a substantial change in circumstances and that the modification serves the children's best interests as outlined in Indiana Code section 31-17-2-8. In the case of In re Marriage of L.C. and T.M. ${ }^{198}$ mother appealed the trial court's denial of her petition to modify the parties' custody arrangement as it related to their two children. ${ }^{199}$ At the time of the original order from 2007, the parties' children were six and eight years old and the parties shared legal and physical custody, although mother resided in Carmel and father resided in Mooresville. ${ }^{200}$ The children attended school in Carmel. ${ }^{201}$

Mother filed her petition to modify custody in June 2012, indicating a substantial change in circumstances existed, namely due to the long distance between the parties' residences, the children's desires to live primarily with mother, and mother's belief that the children would benefit from a more

193. Id. at 34 (citing IND. CoDE $\S 31-17-2.2-1$ (2011)).

194. Id. at 39.

195. 17 N.E.3d 342 (Ind. Ct. App. 2014).

196. Id. at 343 .

197. Id. at 346-49.

198. 996 N.E.2d 403 (Ind. Ct. App. 2013).

199. Id. at 404 .

200. Id.

201. Id. 
structured routine. ${ }^{202}$ A hearing on mother's petition was conducted wherein the guardian ad litem ("GAL") recommended a modification of parenting time in light of the children's increasing hostility toward father and the potential for irreparable harm for his relationship with the children. ${ }^{203}$ The GAL's recommendation for modification was based upon a number of interviews, including with the parents, the stepparents, the children, the parenting coordinator, a therapist, a prior GAL appointed to the case, and the Carmel soccer coach. ${ }^{204}$ The court denied mother's petition and mother subsequently appealed. ${ }^{205}$

The court of appeals noted that it will only reverse a decision of the trial court if manifest abuse of discretion exists, which occurs when the decision is against the logic and effect of the facts before the court. ${ }^{206}$ While citing the cautionary language of D.C. v. J.A.C. ${ }^{207}$ the court ultimately found that the trial court abused its discretion in denying mother's petition to modify given the substantial change in the children's ages and wishes, and the evidence before the court, namely the reports and testimony presented by experts such as the GAL, Parenting Coordinator, and other professionals that supported the finding that a modification was in the children's best interests. ${ }^{208}$

Pitcavage v. Pitcavage deals with the modification of custody after a preliminary order in a dissolution of marriage case. ${ }^{209}$ The court appointed a custody evaluator upon request from father. ${ }^{210}$ After the custody evaluator submitted his report to the trial court, which recommended father be awarded primary physical and sole legal custody, mother retained a second custody evaluator to perform another evaluation. ${ }^{211}$ Father then hired a third expert to critique both evaluators' reports. ${ }^{212}$ After three days of trial, the trial court awarded legal and physical custody to father, and parenting time to mother, subject to her engagement in counseling. ${ }^{213}$ Mother appealed. ${ }^{214}$

Upon review, the court of appeals, in contrast to the finding of L.C. v. T.M., found the trial court's findings were supported by the record and the experts in

202. Id. at 405 .

203. $I d$.

204. Id.

205. Id. at 406 .

206. Id. at 407 (citing Fields v. Fields, 749 N.E.2d 100, 107-08 (Ind. Ct. App.), trans. denied, 761 N.E.2d 417 (Ind. 2001)).

207. Id. at 408-09 (citing D.C. v. J.A.C., 977 N.E.2d 951, 956 (Ind. 2012) (referencing deference to trial courts in light of their unique, direct interactions with the parties face-to-face, over an extended period of time, thereby enabling trial courts to assess credibility and character).

208. Id. at 410-12.

209. Pitcavage v. Pitcavage, 11 N.E.3d 547 (Ind. Ct. App. 2014).

210. Id. at 552 .

211. Id.

212. Id.

213. Id.

214. Id. 
the case. ${ }^{215}$ The Pitcavage discussion outlines not only the importance of the quality of experts and their efforts, but identifies ways practitioners can assist clients during custody disputes when engaging in evaluations, investigations, and assessments. Pitcavage is notable for its thorough review of the investigative work provided by the experts and the implications of involving experts when assessing fee allocations for the use of such experts. ${ }^{216}$ The authors find this opinion to be significant and recommend a full review of this appellate court decision.

4. Other Procedural Pitfalls in Custody Decisions. - In a few final notable cases on custody modifications, we focus on procedural issues that may arise during heated custody proceedings involving, typically, high conflict parents. Bailey v. Bailey is one of the few published cases in which a trial court issued an order involving a parallel parenting ${ }^{217}$ time order. ${ }^{218}$ Before the trial court in Bailey were petitions from both parents relating to parenting time restrictions and multiple contempt issues. ${ }^{219}$ After the hearing on these petitions, the trial court issued a sua sponte order modifying custody from mother as the primary physical custodian to a joint legal and physical custody arrangement between the parties with a parallel parenting time order per the Indiana Parenting Time Guidelines. ${ }^{220}$

The court of appeals held that the trial court abused its discretion as neither party had filed a petition to modify, and the trial court, therefore, had no authority to issue a modification order. ${ }^{221}$ In its analysis, the court reminds practitioners that upon a petition for modification, the trial court has the authority to award a modification in favor of either party, not just the party petitioning for the modification. ${ }^{222}$ The court also noted that ordering a parallel parenting plan would not have been an abuse of discretion if the trial court had maintained the parties' existing custody arrangement. ${ }^{223}$

Further, when issuing an order modifying custody, it is imperative that a thorough evidentiary hearing occur at the trial level and that the trial court make the requisite findings warranting the same. In Wilson v. Myers the Indiana Supreme Court issued strong language for practitioners and judges involved in

215. Id. at 569 .

216. Id. at 553-58, 566-67.

217. Parallel parenting is for limited cases where the trial court determines that the parents are in high conflict and such an order is necessary to protect the child's well-being. IND. CT. R. app., tit. 34, § IV (2013) (Ind. Parenting Time Guidelines). "In parallel parenting, each parent makes day-to-day decisions about the child while the child is with the parent." Id. Communication between the parents should be limited and usually in writing, except in emergencies. Id. "Appropriate counseling professionals are recommended to help parents handle parallel parenting arrangements." Id.

218. Bailey v. Bailey, 7 N.E.3d 340, 343 (Ind. Ct. App. 2014).

219. Id. at $342-43$.

220. Id. at 343 .

221. Id. at 345 .

222. Id. at 344 (citing Meneou v. Meneou, 503 N.E.2d 902, 904-05 (Ind. Ct. App. 1987)).

223. Id. at 346 . 
custody disputes. ${ }^{224}$ In this case, the parties divorced in 2006 and physical custody of the two children was awarded to father. ${ }^{225}$ Mother then filed a motion to modify physical custody of one of the parties' children and the parties were referred to the Domestic Relations Counseling Bureau, which recommended the parties and children engage in counseling. ${ }^{26}$ When counseling efforts were ineffective, the trial court obtained permission from the parties to speak directly with the counselor. ${ }^{227}$ The trial court then set a modification hearing for March $19,2012 .{ }^{228}$

The parties, their attorneys, and the family counselors were present at the hearing and, despite the ability to hear testimony from relevant parties and experts, the trial judge announced that she was ready to rule on mother's motion for modification without hearing from any witnesses. ${ }^{229}$ Father then requested an evidentiary hearing, which the trial court denied and the trial court granted custody of both children to mother, who lived in a different state. ${ }^{230}$ Father appealed. $^{231}$

Upon granting transfer from the court of appeals, the Indiana Supreme Court found a number of deficiencies in both the trial court's record and order, namely, the blatant lack of evidence relating to a substantial change in circumstances and consideration of the best interest factors. ${ }^{232}$ The clear language articulated in Wilson, found in the Indiana Supreme Court's opening paragraph, should be taken to heart by all family law practitioners: "When parents fight each other, it is often the children who suffer. When parents litigate against each other, however, the laws and legal system have explicit mechanisms and considerations aimed specifically at protecting the children caught in the middle." ${ }^{.33}$ Ultimately, these mechanisms and considerations were not followed and, as a result, the Indiana Supreme Court's conclusion, vacating the trial court order and remanding for a proper evidentiary hearing while maintaining the status quo to minimize further disruption, showed the court's concern for the stability of the children which was overlooked by the trial court. ${ }^{234}$

\section{B. Parenting Time}

Appellate court decisions during the survey period covered the notable issues of conditions and standards for supervised parenting time, parenting time, and

224. Wilson v. Myers, 997 N.E.2d 338 (Ind. 2013).

225. Id.

226. Id. at 338-39.

227. $I d$. at 339 .

228. $I d$.

229. $I d$.

230. Id.

231. Id.

232. Id. at 339-41.

233. Id. at 338 .

234. Id. at 341-42. 
modification orders for non-biological children of one of the parties.

1. Supervised Parenting Time Determinations.-Indiana appellate courts have long held that noncustodial parents' time with their children is a sacred and precious privilege. ${ }^{235}$ As such, imposing supervised parenting time requires specific findings from the trial court after an evidentiary hearing. ${ }^{236}$ Two decisions were issued during the survey period which articulated the importance of the specificity required in findings when ordering supervised parenting time. These cases also offer guidance for practitioners when presenting evidence on the issue of supervised parenting time.

In Hatmaker v. Hatmaker, the court of appeals reviewed a decision by the trial court denying father's request to institute unsupervised parenting time. ${ }^{237}$ In the original divorce decree, father's parenting time was ordered to be supervised as father was convicted of committing battery on mother prior to the parties' decree of dissolution in November 2011. ${ }^{238}$ Father's supervised parenting time was also contingent upon his completion of domestic violence counseling and parenting classes, which he subsequently completed. ${ }^{239}$ Father also continued to exercise parenting time with the parties' child through Kids' Voice, ${ }^{240}$ a child advocacy agency that represents children during legal actions and also provides supervised parenting time facilities. ${ }^{241}$ Father's original supervised parenting time was presumably based upon Indiana Code section 31$14-14-5 .^{242}$

In January 2013, father filed a motion for unsupervised parenting time, as two years had passed since the domestic violence incident that created the original presumption of supervised parenting time. ${ }^{243}$ Father also noted that the cost of supervised parenting time at Kids' Voice restricted his parenting time and due to his lack of funds, Kids' Voice was no longer willing or able to maintain his supervised parenting time. ${ }^{244}$ After an evidentiary hearing, the trial court denied father's motions, and after filing a motion to correct error, which was also denied, father appealed. ${ }^{245}$ Hatmaker's appeal involved an abuse of discretion in the trial court's refusal to modify child support as requested by father as welli, ${ }^{246}$

235. McCauley v. McCauley, 678 N.E.2d 1290, 1292 (Ind. Ct. App.), trans. denied, 690 N.E.2d 1180 (Ind. 1997).

236. Id. at 1291-92.

237. 998 N.E.2d 758, 759 (Ind. Ct. App. 2013), trans. denied, 25 N.E.3d 746 (Ind. 2015).

238. Id. at 760 .

239. Id.

240. Id.

241. Id.

242. IND. CODE $\S 31-14-14-5$ (2011) (provides a presumption of supervised parenting time in cases of domestic violence where the domestic or family violence was witnessed or heard by the noncustodial parent's child).

243. Hatmaker, 998 N.E.2d at 760.

244. $I d$.

245. Id.

246. Id. at $762-63$. 
however, we focus on the supervised parenting time issue.

In its analysis, the court of appeals articulated that all visitation controversies are governed by the foremost consideration for the best interest of the child. ${ }^{247}$ The restriction of parenting time to a supervised situation is governed by Indiana Code section 31-17-4-1(a), which requires a hearing and a finding that parenting time by the noncustodial parent might endanger the child's physical health or significantly impair his or her emotional development. ${ }^{248}$ Further, the party seeking to restrict the parenting time rights bears the burden of proof when making such requests. ${ }^{249}$

At the hearing, mother testified that father had obtained mother's address, sent letters, and visited the parties' child at school. ${ }^{250}$ She also testified about her continued fear of father, particularly as a decapitated rabbit was left at her residence, which she suspected was perpetrated by father. ${ }^{251}$ In its order, the trial court did not make a finding of endangerment or impairment to the child's emotional development and instead ordered a modification of parenting time which was to be by agreement of the parties, at any time, as a parenting time modification presented no likely danger to the child. ${ }^{252}$ The order, in effect, allowed mother the ability to enforce supervision of father's parenting time at her discretion and was erroneous based on its inconsistent application of statutory authority. ${ }^{253}$ Accordingly, the court of appeals reversed the trial court's ruling, remanding with instructions that the trial court must either enter an order which contained sufficient findings per statute or issue an order that does not contain such parenting time restrictions. ${ }^{254}$

The second case addressing supervised parenting time, Meisbergerv. Bishop, also outlined the importance of specific findings in cases where supervised parenting time is requested. ${ }^{255}$ In the early 1990 s, father was sentenced to serve forty-eight years with the Department of Correction ("DOC") for a conviction of murder and theft. ${ }^{256}$ In 2007, he was placed on probation and fathered a child with mother, and the parties later married. ${ }^{257}$ The parties were divorced in 2009 and in 2011 father was granted parenting time pursuant to the Indiana Parenting Time Guidelines. ${ }^{258}$ In 2012, father violated the terms of his probation and the

247. Id. at 760 (quoting Marlow v. Marlow, 702 N.E.2d 733, 735 (Ind. Ct. App. 1998), trans. denied, 690 N.E.2d 1180 (Ind. 1997)).

248. IND. CODE § 31-17-4-1(a) (2005).

249. Hatmaker, 998 N.E.2d at 761 (citing D. B. v. M.V.B., 913 N.E.2d 1273, 1274 (Ind. Ct. App. 2009)).

250. Id. at 762 .

251. Id.

252. Id.

253. $I d$.

254. Id. (citing Walker v. Nelson, 911 N.E.2d 124, 130 (Ind. Ct. App. 2009)).

255. Meisberger v. Bishop, 15 N.E.3d 653 (Ind. Ct. App. 2014).

256. Id. at 654 (citing Meisberger v. State, 640 N.E.2d 716, 719 (Ind. Ct. App. 1994)).

257. Id.

258. Id. at 655 . 
State requested a revocation of his suspended sentence, thereby requiring father to serve the remainder of his sentence in the DOC. ${ }^{259}$ In 2013, father requested a modification of parenting time and subsequently filed numerous other pro se pleadings, as the trial court denied the same without hearing; however, his request to modify parenting time was ultimately heard over five months later. ${ }^{260}$

The trial court issued an order which prohibited father's face-to-face parenting time with the child at the DOC, based mainly upon the reluctance of mother and grandparents to transport the child. ${ }^{261}$ Father then appealed as the trial court did not issue findings that in-person parenting time with father at the DOC would endanger the child or impair the child's emotional development. ${ }^{262}$ The court of appeals applied the analysis used in Rickman v. Rickman, indicating that the plain language of the Indiana Parenting Time Guidelines applies even when a parent is incarcerated. ${ }^{263}$ As in Rickman, and the decision in Hatmaker, the court remanded the case to the trial court to make the necessary determinations and findings regarding supervised parenting time or conduct other proceedings consistent with the requirements of Indiana law when establishing parenting time. ${ }^{264}$

2. Parenting Time and Custody Orders for Non-Biological Children.-The cases in this section relate to parenting time or custody which was awarded to a parent who was not the biological parent of a child, whether a child born during the marriage or from the other party's previous relationship. These cases also review the basis on which the court finds such orders appropriate in light of the legal challenges that exist when issuing such orders.

In Myers v. Myers, father objected to mother's proposed relocation to Texas with H.M., who was only a biological child to mother. ${ }^{265}$ During the parties' divorce proceedings in 2006 , the trial court found that H.M., who was one of the parties' six children, was not a biological child of father; however, the parties always held father as H.M.'s biological father, as was reflected on H.M.'s birth certificate. ${ }^{266}$ At the dissolution hearing, mother also testified that father should be awarded Indiana Parenting Time Guideline parenting time with H.M. and the court found that it would not be in H.M.'s best interest to have a parenting time arrangement with father different from the other siblings. ${ }^{267}$ Six years later, in 2012, the parties' modified their custody and parenting time arrangement such that father had custody of the parties' son but custody of H.M. remained primarily with mother. ${ }^{268}$

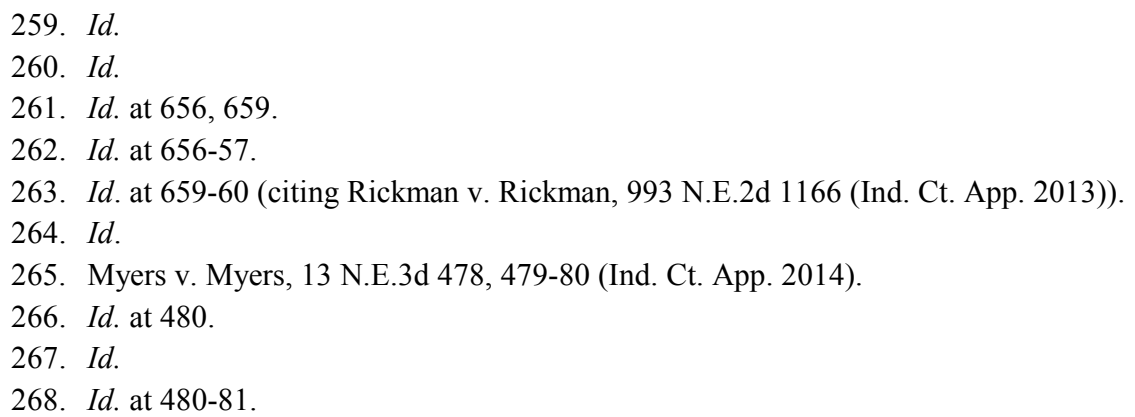


Mother filed her notice of intent to relocate to Texas with H.M. in 2013 shortly after the parties' 2012 modification, citing financial reasons for the relocation. ${ }^{269}$ Father and the GAL filed objections; and, prior to the relocation hearing, mother quit her job in Indiana and accepted a position in Texas. ${ }^{270}$ After the hearing, the trial court found that mother had not established her burden of proving a good faith and legitimate reason for relocation and found that the relocation was not in H.M.'s best interests. ${ }^{271}$

In its order, the trial court denied mother's request to relocate, and stated that if she did choose to relocate, father was to be awarded custody of H.M. with mother having parenting time pursuant to the Indiana Parenting Time Guidelines. ${ }^{272}$ Mother then appealed, contending that H.M. was not a child of the marriage and, therefore, father was not a non-relocating parent having the authority to object under Indiana's relocation statute. ${ }^{273}$ Mother also argued on appeal that the trial court erred in denying her relocation request; ${ }^{.74}$ however, we focus on the first issue on appeal regarding father's authority to object to mother's relocation.

The court of appeals found that, although it was established in the parties' divorce that H.M. was not the biological child of father, mother did not provide any direct, clear, and convincing evidence to rebut the presumption that father was not the assumed father of H.M. ${ }^{275}$ There was no mention in the divorce decree of the traditional evidence that would rebut this presumption, such as impotence, absence during the entire time the child must have been conceived, presence only in circumstances proving no sexual intercourse, sterility during the time of the child's conception, or DNA testing to establish H.M.'s paternity. ${ }^{276}$ In addition to the evidentiary issue, the court of appeals noted that mother never challenged the trial court's findings over the course of seven years during and after the divorce. ${ }^{277}$ Accordingly, the court of appeals applied the doctrine of laches, finding that there was inexcusable delay, implied waiver arising from the acquiescence in the existing condition, and circumstances that would cause prejudice to an adverse party, most notably, the child. ${ }^{278}$

The court of appeals affirmed the trial court's decision regarding the validity of father's objection to relocation and the denial of mother's relocation; however, the court did reverse the trial court's automatic change of custody to father should mother relocate to Texas, finding that an automatic modification based on

269. Id. at 481 .

270. Id.

271. $I d$.

272. Id.

273. Id.

274. Id. at 481-82.

275. Id.

276. Id. at 482-83 (citing In re Paternity of I.B., 5 N.E.3d 1160, 1161 (Ind. 2014); Minton v. Weaver, 697 N.E.2d 1259, 1260 (Ind. Ct. App. 1998), trans. denied, 706 N.E.2d 175 (Ind. 1998)).

277. Id. at 483 .

278. Id. at $483-84$. 
a future event was error. ${ }^{279}$ It is also important to note that the court left the question of whether a GAL may object in a relocation matter open for further review, finding that no determination of this issue was necessary as father had the authority to object to mother's relocation. ${ }^{280}$

Fry v. Fry ${ }^{281}$ addressed a modification of custody; however, in Fry, the child at issue was mother's prior-born daughter. ${ }^{282}$ The parties agreed during the divorce that father's parenting time rights included time with mother's prior-born daughter, K.D., who was not the biological child of father. ${ }^{283}$ The parties' divorce decree also made no mention of K.D.'s biological father. ${ }^{284}$ In 2012, seven years after the original custody agreement, father filed an emergency petition for Modification of Custody, Parenting Time, and Child Support for both K.D. and the parties' biological child which alleged that mother's degenerative illness no longer allowed her to physically care for the minor children. ${ }^{285}$

The trial court granted father's petition and awarded mother supervised parenting time in order to protect the emotional health of the children. ${ }^{286}$ In 2013, mother filed her own Petition for Modification asserting that the court's previous order was based on father's allegation of an emergency condition which was no longer applicable, as well as a motion to declare the court's order from 2012 void, arguing the trial court had no jurisdiction to award custody of K.D. to Father. ${ }^{287}$ The trial court denied mother's motions, finding the change in circumstances and conditions relating to father's emergency requests still existed. ${ }^{288}$ Mother then appealed. ${ }^{289}$

In its analysis, the court of appeals clarified mother's mischaracterization of a jurisdictional issue, finding that Indiana Code section 31-17-2-25 allows for emergency placement of a child with a person other than a parent if the custodial parent becomes unable to care for the child. ${ }^{290}$ Further, the court of appeals cited Indiana case law $^{291}$ and a code section ${ }^{292}$ which allow for a trial court to award custody of a child to a natural or adoptive parent, or to a de facto custodian. ${ }^{293}$ Thus, father qualified as a de facto custodian of K.D. as the child was three at the

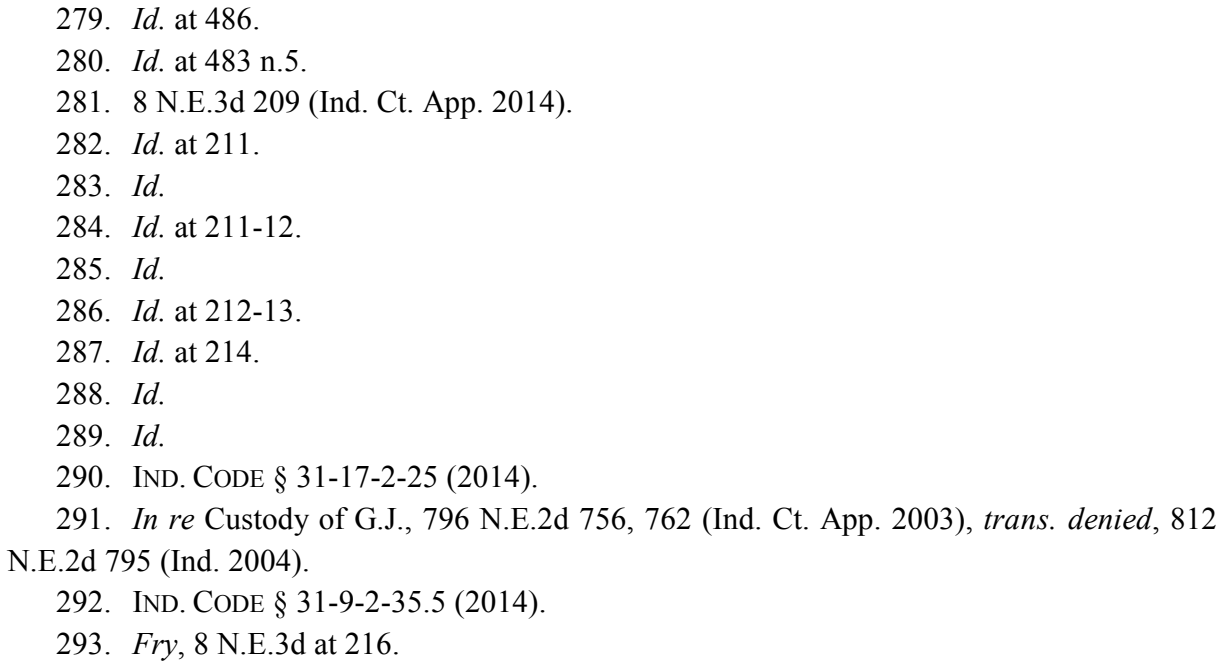


time of the parties' marriage and seven at the time of the parties' dissolution. ${ }^{294}$ Finally, the court of appeals noted that mother did not appeal the trial court's modification order from 2012, and mother instead abided by the terms of the order until the time of her appeal, which was based upon her own modification petition from $2013 .^{295}$

\section{Grandparent Visitation}

As Indiana recognizes the Grandparent Visitation Act ("the Act"), ${ }^{296}$ appellate decisions continue to juggle the delicate balance between the fundamental rights of parents as expressed under Troxel v. Granville ${ }^{297}$ and the statutory rights available to grandparents under the Act. ${ }^{298}$ Three major cases relating to grandparent visitation, which are all very fact-sensitive, were issued during the survey period, and are outlined below. Two of these cases included a divided panel of judges and the dissents are summarized accordingly.

In the first case, K.L. v. E.H. ${ }^{299}$ mother appealed the trial court's order granting paternal grandfather's request for visitation. ${ }^{300}$ While married to husband, mother became pregnant with father's child. ${ }^{301}$ Mother and husband were divorced in September 2011, and father committed suicide on October 15, 2011..$^{302}$ After father's death, mother initiated a paternity action alleging she was pregnant with father's child and was due on April 13, 2012. ${ }^{303}$ Mother requested the coroner hold a sample of father's DNA so genetic testing could occur upon the child's birth. ${ }^{304}$ Mother then moved back in with husband. ${ }^{305}$ Prior to the child's birth, grandfather contacted mother and mother invited grandfather and other members of grandfather's family to her baby shower, which they attended. ${ }^{306}$ The child was born on April 4, 2012. ${ }^{307}$

Grandfather visited the child in the hospital, and in early June 2012, mother brought the child to grandfather's house. ${ }^{308}$ After this single visit, grandfather made additional requests to see the child and to receive photos of the child;

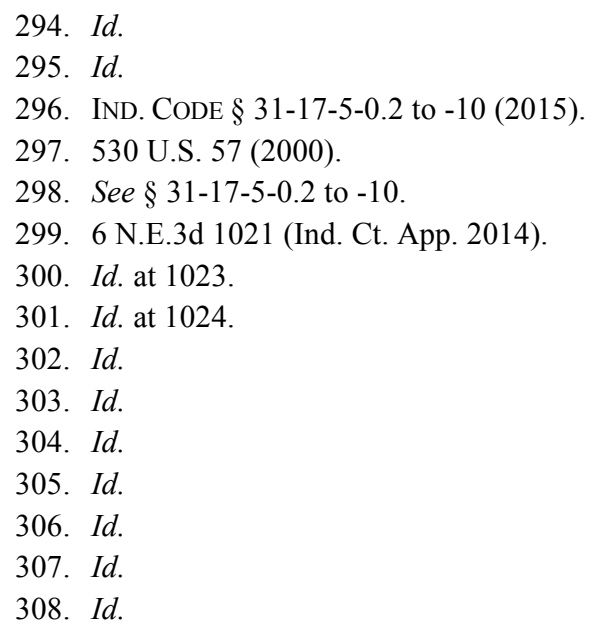


however, mother did not grant these requests. ${ }^{309}$ In August 2012, grandfather filed a petition to intervene in the paternity action, alleging that the child's father was a Navy veteran and the child was potentially eligible for Social Security and military benefits. ${ }^{310}$ After the court found father was the biological father of the child, grandfather filed his verified petition for grandparent visitation in January $2013 .{ }^{311}$

The trial court held a hearing on grandfather's petition and ordered the parties to participate in family counseling and that the process was to be a confidential, mediation-like process. ${ }^{312}$ After mediation was unsuccessful, the trial court held another hearing in May 2013, the testimony from which focused on mother's life, her interactions with grandfather, and her concerns about an award of grandparent visitation involving grandfather. ${ }^{313}$ The trial court, against mother's wishes, awarded visitation to grandfather and set forth a formal visitation schedule. ${ }^{314}$ Mother appealed alleging an abuse of discretion in the trial court's exclusion of the counselor's testimony, which we do not focus on in this summary, and its award of grandparent visitation. ${ }^{315}$

The court of appeals outlined the four factors (hereinafter referred to as the "McCune factors") which govern a determination of grandparent visitation, namely: (1) a presumption that a fit parent's decision about grandparent visitation is in the child's best interests (thus placing the burden of proof on the petitioning grandparents); (2) the "special weight" that must therefore be given to a fit parent's decision regarding non-parental visitation (thus establishing a heightened standard of proof by which a grandparent must rebut the presumption); (3) "some weight" given to whether a parent has agreed to some visitation or denied it entirely (since a denial means the very existence of a childgrandparent relationship is at stake, while the question otherwise is merely how much visitation is appropriate); and (4) whether the petitioning grandparent has established that visitation is in the child's best interests. ${ }^{316}$ Here, the court of appeals noted that the trial court was not obligated to take the "special weight" requirement offered by a parent as a face value explanation ${ }^{317}$ and that an order on grandparent visitation must provide analysis of the evidence presented as weighed by the trial court. ${ }^{318}$ Although mother argued that her facts are similar to those presented in Troxel, the court of appeals disagreed and found no abuse

309. Id.

310. $I d$.

311. Id.

312. Id. at $1025-26$.

313. Id.

314. Id. at 1026-29 (outlining the details of the trial court's findings of fact and conclusions of law).

315. Id. at 1023-24.

316. Id. at 1032 (citing M.L.B. v. M.A.B., 983 N.E.2d 583, 586 (Ind. 2013) (citing McCune v. Frey, 783 N.E.2d 752, 757-59 (Ind. Ct. App. 2003))).

317. Id. (citing Spaulding v. Williams, 793 N.E.2d 252, 260 (Ind. Ct. App. 2003)).

318. Id. at 1032-33 (citing M.L.B., 983 N.E.2d at 589). 
of discretion, holding that the trial court did not find that mother attempted to cut off visitation entirely and had properly applied the other three factors. ${ }^{319}$

Judge Robb, however, wrote a partial dissent regarding the issue of the "special weight" to be given to a fit parent's decision. ${ }^{320}$ The partial dissent focused on the discrepancy in the trial court's order indicating it gave "little to no weight" to mother's concerns about visitation, while "special weight" is the standard required by law. ${ }^{321}$ Judge Robb also offered guidance on a more gradual supervision schedule to address the transition from supervised visits to unsupervised and the frequency of said visits in light of mother's concerns. ${ }^{322}$ What can also be gleaned from the dissent is the potential need for follow-up assessments on visitation to continually evaluate the appropriateness of visits as they progress. ${ }^{323}$

In another divided appellate decision, In re Grandparent Visitation of C.S.N. ${ }^{324}$ mother contested the trial court's award of grandparent visitation to deceased father's parents. ${ }^{325}$ This case details the dissolution of mother's relationship with paternal grandparents from the birth of the child in 2010 through the grandparent's initiation of their visitation action in $2013 .{ }^{326}$ The court of appeals notes that the purpose of grandparents' petition was to obtain overnight visits, which were not allowed by mother; although she continued to permit almost weekly visits several weeks after grandparents filed their petition. ${ }^{327}$ Upon picking up the child from one visit in particular, mother found the child upset and exhibiting atypical behavior. ${ }^{328}$ Mother then terminated all visits between the child and grandparents and thereafter the trial court issued its order granting visitation in October 2013. ${ }^{329}$ The trial court established a six week transition period of supervised and unsupervised visits, and thereafter, grandparents were entitled to visits every other Sunday from 10:00 am to 6:00 pm. ${ }^{330}$ Mother appealed, citing improper findings of fact and conclusions of law, and requested a stay of the trial court's order pending appeal. ${ }^{331}$ The present analysis is based on the trial court's amended findings which were issued in April 2014, upon remand from the Indiana Court of Appeals. ${ }^{332}$

The court of appeals reversed the trial court's decision based, specifically,

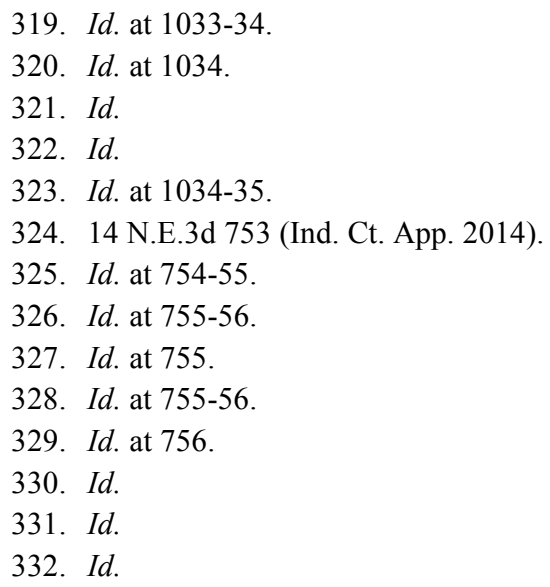


on the misapplication of the first, second, and fourth $\mathrm{McC}$ Cune factors, ${ }^{333}$ citing that the trial court abused its discretion in awarding grandparent visitation as mother previously allowed visitation and acknowledged that the child should continue his relationship with grandparents. ${ }^{334}$ In its analysis, the court focused on the presumption of a fit parent's decision-making and the special weight to be awarded to a decision made in the child's best interests. ${ }^{335}$ Further, the court of appeals criticized the trial court's failure to consider the totality of the testimony from mother's therapist and mother's reliance on this advice when considering the child's visitation with grandparents. ${ }^{336}$

Other issues with the trial court's findings included the failure to consider the totality of the circumstances behind mother's decision to temporarily deny visitation, the grandparents' motives in requesting more visitation than they had previously been allowed, specifically their desire for overnight visitation with the child, as well as the lack of deference awarded to mother's decision-making as a fit parent. ${ }^{337}$ Accordingly, the court vacated the trial court's award of visitation and granted mother the discretion to determine the level of visitation in light of her parental rights and the child's best interests. ${ }^{338}$

Judge Vaidik issued a substantial dissent in this matter which focused on the extended relationship with the child enjoyed by grandparents until they had no other remedy than to pursue legal action against mother to protect their visitation, which had been suddenly and unilaterally terminated by mother. ${ }^{339}$ Judge Vaidik expressed concern about the majority's characterization of grandparents' legal action, specifically as the majority cites grandparents' legal action as a potential contributing factor to the breakdown in the visitation with the child. ${ }^{340}$ Judge Vaidik noted that taking legal action was grandparents' only recourse when mother was, as characterized by the trial court, unlikely to "voluntarily reestablish the grandparent-grandchild relationship without a court order." $" 341$ Because of the discretion of the trial court in weighing the credibility of witnesses and the trial judge's adjudication of the McCune factors, Judge Vaidik dissented from the majority and would have affirmed the trial court's order. ${ }^{342}$

The court of appeals' only unanimous grandparent visitation case examined herein is In re Visitation of A.D. and B.D. ${ }^{343}$ Similar to the previous cases, paternal grandparent, in this case grandmother, appealed the trial court's denial of her petition for visitation; however, the court of appeals affirmed the trial

333. Id. at 758, 761; see also McCune v. Frey, 783 N.E.2d 752, 757 (Ind. Ct. App. 2003).

334. In re Grandparent Visitation of C.S.N., 14 N.E.3d at 761-62.

335. Id. at 758-61.

336. Id. at 758-60.

337. Id at $760-62$.

338. Id. at 762 .

339. Id. at 762-66.

340. Id. at 766 .

341. Id. (citing the trial court's revised order).

342. Id.

343. 18 N.E.3d 304 (Ind. Ct. App. 2014). 
court's decision citing that visitation was not in the children's best interests. ${ }^{344}$ In the present case, mother had two children with father in 2009 and 2011. ${ }^{345}$ Father ceased contact with the children in 2013 and grandmother's only contact with the children before filing her petition for visitation had been during father's parenting time. ${ }^{346}$ Grandmother requested visitation from mother directly before filing her petition; however, mother refused this request. ${ }^{347}$

The trial court affirmed an agreement between the parties regarding a "trial period" of visitation for grandmother in July 2013, which provided grandmother supervised visits each Saturday in July, then two, four-hour blocks of visitation each Saturday in August to be supervised by great-grandparents, and a review hearing was set for September. ${ }^{348}$ This agreement also included a number of specific guidelines and expectations for the parties and their behavior during the exchanges and visits. ${ }^{349}$ Problems arose in August when visits were no longer supervised by mother, namely behavioral and language issues with the children. ${ }^{350}$ The trial court ultimately denied grandmother's petition after applying and analyzing the $\mathrm{McC}$ Cune factors, citing the deference awarded to mother's decision-making as a fit parent which was in the best interests of the children, and grandmother appealed. ${ }^{351}$

Grandmother provided the argument that the trial-period agreement was, in and of itself, an award of grandparent visitation and that the trial court erred in denying her petition as it was to apply a modification standard for her visitation. ${ }^{352}$ The court of appeals disagreed, as the agreement was a provisional order subject to final review as evidenced by the trial court's order and the trial court's application of the McCune factors in its order. ${ }^{353}$ Grandmother's arguments on appeal were unsuccessful in light of the facts presented to the trial court, and grandmother's failure to meet the heightened burden of proof to rebut the presumption given to mother's decision-making, particularly given mother's legitimate concerns for safety and appropriate behavior of the children when with grandmother. ${ }^{354}$

\section{CHILD SUPPORT}

Indiana provides for a standard calculation of child support as outlined in the Indiana Child Support Guidelines ("the Guidelines"), and while the Guidelines

\footnotetext{
344. Id. at 305 .

345. Id.

346. Id. at 305-06.

347. Id. at 306 .

348. $I d$.

349. Id.

350. $I d$.

351. Id. at 307-08.

352. Id. at 309-10.

353. Id. at 310 .

354. Id. at 310-11.
} 
provide direction on the factors used to calculate support, certain methods of calculation are left to the discretion of the courts. Further complicating the issue of support is that the Guidelines provide definitive provisions for calculating support but also leave room for flexibility so as to mitigate harsh or unreasonable results. ${ }^{355}$ In many of the child support cases, the appellate courts offered guidance on the balance between the processes outlined in the guidelines and the need for flexibility.

\section{A. Modification}

As with parenting time and custody, the circumstances of the parties often change after an initial order of child support. The cases below involves a child support modification with respect to health insurance credits and allocations of social security benefits.

In Johnson v. Johnson, ${ }^{356}$ the parties disagreed over the trial court's calculation of child support, particularly its treatment of father's Social Security Retirement benefits and mother's health insurance credit. ${ }^{357}$ The parties divorced in 1999 and had two children during the marriage. ${ }^{358}$ Father was ordered to pay $\$ 90$ per week in support and was to maintain health insurance for the children, with the parties equally sharing the children's uninsured healthcare expenses. ${ }^{359}$ Upon father's retirement in 2003, he no longer received group health coverage and the parties modified father's child support to $\$ 75$ per week, per child, or $\$ 150$ per week total, as mother was allocated the credit for the children's health insurance premium. ${ }^{360}$ In 2011, father sought a second modification as he began receiving Social Security Retirement benefits and mother, in turn, received a monthly benefit for each child. ${ }^{361}$

During this second modification proceeding, the parties disagreed on the credit mother should receive for health insurance for the children as well as the application of the Social Security Retirement benefits for the children which were received by mother. ${ }^{362}$ Mother had three options for health insurance plans: individual employee, employee plus one, and a family plan. ${ }^{363}$ Father requested that the trial court only credit mother for the difference between the cost of the family plan and the employee plus one plan, or $\$ 26.75$ per week. ${ }^{364}$ Mother, however, requested her health care credit be two-thirds the cost of the family plan

355. IND. CT. R. app., tit. 34, Guideline 1, Commentary (1989) (Ind. Child Support Rules and Guidelines).

356. 999 N.E.2d 56 (Ind. 2013).

357. Id. at 57.

358. $I d$.

359. Id.

360. Id.

361. Id. at 57-58.

362. Id. at 58 .

363. Id.

364. Id. 
less the cost of her individual plan, or \$76.67 per week, and the trial court agreed with mother's calculation. ${ }^{365}$ Here it is important to note that mother had a subsequently born child, whom she also covered on this family plan. ${ }^{366}$ In applying the Social Security Retirement benefits, the trial court credited mother with this additional income in its support calculation, thereby reducing father's support obligation from $\$ 150$ per week to $\$ 138$ per week. ${ }^{367}$

Father appealed on a number of issues, most of which were affirmed in an unpublished opinion that is not analyzed here. ${ }^{368}$ The court of appeals did, however, reverse the trial court's decision on the health insurance credit and application of Social Security Retirement benefits and both parties appealed. ${ }^{369}$ However, on transfer, the Indiana Supreme Court affirmed the trial court's decision, acknowledging that, although individual courts may adopt different approaches when establishing a support obligation, when the Guidelines do not specify a bright-line procedure, courts must tailor child support orders based on the individual circumstances of the parties and apply the Guidelines to the circumstances with their best judgment, as the trial court did in this instance. ${ }^{370}$

In analyzing the calculation of mother's health insurance credit, the Indiana Supreme Court cited language from Indiana Child Support Rules and Guidelines, Guideline 3(E)(2) and the corresponding commentary requiring that the children's portion of the health insurance premium be credited, which gives rise to this issue on appeal. ${ }^{371}$ Here, father argued that the trial court's calculation of the health insurance premium includes a portion for mother's subsequently born child, but the supreme court held that although the trial court's methodology may not have been the most mathematically accurate means to calculate the appropriate health insurance credit due to mother's subsequently born child, the trial court used its best judgment in assessing the children's health insurance premium. ${ }^{372}$ Father's proposal for the health insurance credit, furthermore, was not a realistic option in light of the plans available through mother's employer, as his request to base the credit consistent with an "employee plus one" policy would not cover mother and the parties' two children even without considering mother's subsequently born child. ${ }^{373}$

Father's Social Security Retirement benefits were also a factor to be considered when establishing the new child support figure. ${ }^{374}$ With this issue, the

365. Id.

366. Id.

367. Id.

368. See Johnson v. Johnson, 979 N.E.2d 718 (Ind. Ct. App. 2012), vacated, 999 N.E.2d 56 (Ind. 2013).

369. Johnson v. Johnson, 999 N.E.2d 56 (Ind. 2013).

370. Id at 60 .

371. Id. at 59-60; see IND. CT. R. app., tit. 34, Guideline 3(E)(2) (1989) (Ind. Child Support Rules and Guidelines).

372. Johnson, 999 N.E.2d at 59-60.

373. Id.

374. Id. at 60; see IND. CT. R. app., tit. 34, Guideline 3(G)(5) (1989) (Ind. Child Support Rules 
Guidelines offer assistance in the application of these benefits; however, language from Guideline 3(G)(a)(2)(i) articulates that Social Security Retirement benefits are to be credited to the noncustodial parent at the court's discretion, per the Indiana Supreme Court's decision in Stultz v. Stultz and in the later court of appeals decision in Thompson $v$. Thompson. ${ }^{375}$ Here, the trial court added the children's Social Security Retirement benefits to mother's income, which had the effect of reducing father's overall support obligation. ${ }^{376}$ Father requested a dollar-for-dollar credit that would have reduced his child support obligation to zero and the Indiana Supreme Court disagreed with father's argument, finding father received appropriate credit for the Social Security Retirement benefits directed towards the children as these sums were imputed into mother's income, thereby reducing father's overall support. ${ }^{377}$ Accordingly, the Indiana Supreme Court found that the trial court fulfilled the spirit of the Guidelines in applying the unique facts and circumstances of the parties in conjunction with the procedures and factors outlined in the Guidelines to fashion an obligation using the trial court's best judgment. ${ }^{378}$

\section{B. Contempt Actions and Arrearage Issues}

This section covers a variety of cases which review issues involving nonpayment of support, calculation of support arrearages, and the payment of arrearages.

1. Right to Counsel in Contempt Actions. - In Moore v. Moore, ${ }^{379}$ the parties were divorced in 2009 and father was ordered to pay support in June 2013. ${ }^{380}$ Mother later filed a motion for rule to show cause for non-payment of child support as father had paid less than $\$ 50$ since the order setting his weekly support obligation at $\$ 139$ per week. ${ }^{381}$ At the rule to show cause hearing, father requested an attorney as mother sought a thirty day suspended jail sentence for father pending a compliance hearing. ${ }^{382}$ The trial court denied father's request, stating that any jail sentence would be suspended. ${ }^{383}$ The trial court conducted an evidentiary hearing and found father in contempt, sentencing him to a suspended, thirty day jail sentence. ${ }^{384}$ The trial court did acknowledge that it would revisit father's request for counsel at a compliance hearing set in January

and Guidelines).

375. Johnson, 999 N.E.2d at 61-63 (citing and Thompson v. Thompson, 868 N.E.2d 862 (Ind.

Ct. App. 2007); Stultz v. Stultz, 659 N.E.2d 125 (Ind. 1995)).

376. Id. at 62 .

377. Id. at 62-63.

378. Id. at 57,63 .

379. 11 N.E.3d 980 (Ind. Ct. App.), trans. denied, 20 N.E.3d 851 (Ind. 2014).

380. Id. at 981 .

381. Id.

382. Id.

383. Id.

384. Id. 
$2014 .^{385}$

The court of appeals held that the trial court made a prima facie error in denying father's request for an attorney as Indiana case law clearly requires the appointment of counsel where the possibility exists that an indigent defendant may be incarcerated for the failure to pay child support. ${ }^{386}$ As this clear possibility existed, the trial court should have conducted a hearing to determine if father was indigent and entitled to representation by pauper counsel at the initial hearing, not just at the compliance hearing after father was already found in contempt. ${ }^{387}$ The court also noted in its opinion that this right to counsel exists whether a contempt action is initiated by an individual or the State under its Title IV-D authority. ${ }^{388}$ Finding error, the court reversed the trial court's decision and remanded the same for a new contempt hearing with counsel present. ${ }^{389}$

2. Arrearage Calculations and the Impact of a Paternity Dismissal.Douglas v. Spicer ${ }^{390}$ presents the issue of the implications of a paternity order when the paternity cause is dismissed and how the dismissal impacts an arrearage determination. ${ }^{391}$ Mother and father never married but lived together in February 1994 when the child was born. ${ }^{392}$ Father was listed on the child's birth certificate and the parties continued to cohabitate until the child was approximately four years old. ${ }^{393}$ In December 2004, mother initiated a paternity action, and a provisional order was entered by the trial court in February 2005, ordering father to pay $\$ 200$ per week in child support to mother, which father did not do. ${ }^{394}$

Later, in October 2005, the court dismissed the paternity action after the parties failed to appear at a status hearing. ${ }^{395}$ Father, however, continued to provide financial support, including health insurance for the child, and the parties also began cohabitating again in $2010 .{ }^{396}$ Two years later, mother filed a motion to re-open the case which was granted. ${ }^{397}$ Mother then requested the trial court to establish an arrearage and, upon discovering mother's legal undertakings, father moved out again but continued to financially support the child. ${ }^{398}$

After a hearing, the trial court found that father never paid the $\$ 200$ per week as ordered in February 2005 and calculated his arrearage based off the thirtythree weeks that passed between the order establishing his support obligation and

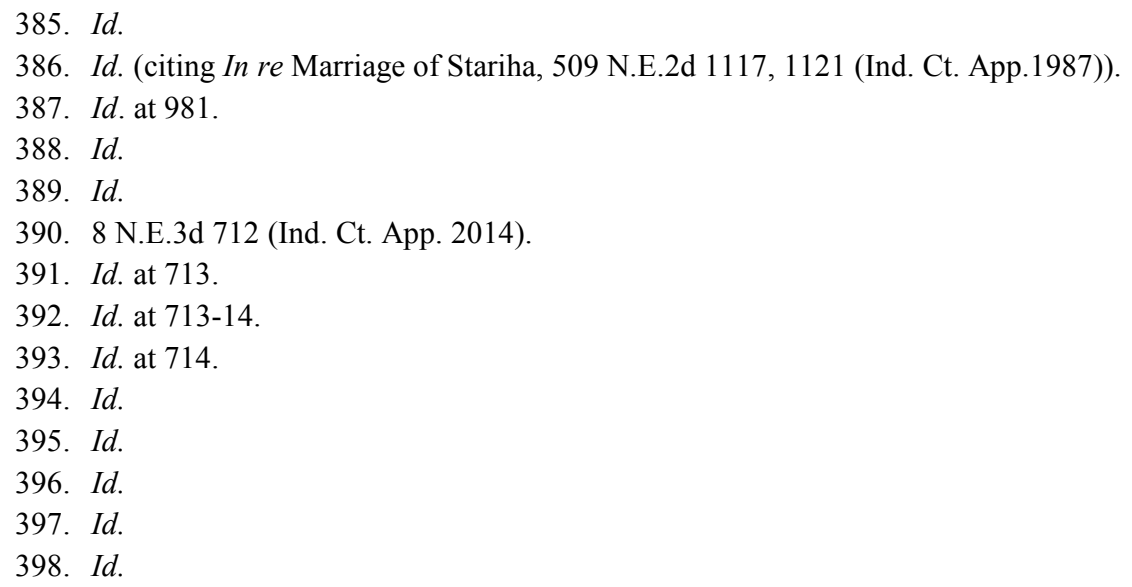


the order dismissing the case in October 2005. ${ }^{399}$ Mother then filed a motion to correct error stating the arrearage was $\$ 74,000$, which the trial court denied, and the child, L.S., by next friend, filed a motion to intervene, which the trial court granted. ${ }^{400}$

On appeal, mother argued that father's support obligation did not terminate with the trial court's dismissal of the paternity action. ${ }^{401}$ The court of appeals disagreed, citing Indiana Code section 31-15-4-14 which speaks to the relationship between a dismissal of a dissolution proceeding and the impact on a provisional order issued therein, namely that once an action is dismissed, any orders pertaining thereto are also dismissed. ${ }^{402}$ This same principle, the court of appeals reasoned, should be applied in paternity matters as established in In re Paternity of V.A.M.C. ${ }^{403}$

Mother further argued that even if the provisional order was dismissed, father failed to provide support for the child arising from a common law duty. ${ }^{404}$ Again, the court did not agree with mother's argument, instead finding that father provided over fifty percent of the child's financial support, including health insurance, clothing, food, school expenses, and other typical costs incurred in raising a child. ${ }^{405}$ In her final argument, mother alleged that even if the parties did not involve the courts in their agreement regarding the support of their child, such agreement was contrary to public policy. ${ }^{406}$ Again, the court of appeals was unconvinced that the facts of the case, when considered in light of the Indiana Supreme Court's decision in Straub v. B.M.T., ${ }^{407}$ established that the agreement between father and mother to not exchange formal child support contracted away any of the child's rights, as the record showed father contributed to over fifty percent of the care and support of the child, consistent with the holding of K.S. v. R.S. ${ }^{408}$ Accordingly, the court found that both parties provided for their child, that the provisional order terminated when the action was dismissed as neither party pursued the issues therein, and that the trial court properly calculated father's arrearage based off the facts in the record. ${ }^{409}$

3. Requests for Hearing and Garnishment of Inmate Trust Accounts.-The court of appeals analyzed a trial court's abuse of discretion in denying father's request for a hearing to establish arrears and contest the garnishment of his

399. Id.

400. $I d$.

401. Id. at 715 .

402. Id. (citing IND. CODE $§ 31-15-4-14$ (2015)).

403. Id. (citing In re Paternity of V.A.M.C., 768 N.E.2d 990, 1000 n.4 (Ind. Ct. App.), reh'g granted, 773 N.E.2d 359 (Ind. Ct. App. 2002)).

404. Douglas, 8 N.E.3d at 715.

405. Id.

406. Id.

407. 645 N.E.2d 597, 600 (Ind. 1994).

408. 669 N.E.2d 399, 405-06 (Ind. 1996).

409. Douglas, 8 N.E.3d at 716. 
inmate trust account in In re Paternity of J.M. ${ }^{410}$ Mother commenced an action to establish support for the parties' two children in 2007. ${ }^{411}$ In her petition to establish support, mother signed an agreement authorizing the State of Indiana to establish and enforce support actions under its Title IV-D authority and a support order was issued for $\$ 31$ per week. ${ }^{412}$ In June 2011, father filed a request to modify his support because mother had lost custody of the children, and as he was incarcerated, requested the trial court suspend his child support obligation. ${ }^{413}$ In a chronological case summary entry, the trial court ordered father's support to be suspended until his release from the Department of Correction and ordered father to contact the Title IV-D court upon his release. ${ }^{414}$

In April 2013, father requested a hearing to determine his arrearage and the garnishment of his inmate trust fund account, indicating that his trust account was being garnished per the court's original order. ${ }^{415}$ The trial court denied father's request but found that no current support obligation existed. ${ }^{416}$ The trial court also found that father did owe an arrearage and he should continue to pay toward the same, thereby allowing the Title IV-D prosecutor to enforce child support collection efforts on arrears. ${ }^{417}$ Father then appealed. ${ }^{418}$

The court of appeals held that father waived his argument that the original support calculation was unreasonable as he failed to appeal or challenge the order in any way. ${ }^{419}$ However, the original support order utilized to garnish father's inmate trust fund account only related to accruing support and no record existed regarding an order establishing an arrears balance or requiring payments on the same. ${ }^{420}$ The trial court also never heard any evidence regarding father's income or ability to pay while incarcerated and the court never established a specific amount of or payment schedule for father's accumulated arrearage. ${ }^{421}$ Accordingly, the court of appeals reversed the trial court's decision and remanded with instructions for the trial court to conduct an evidentiary hearing to determine father's support arrearage and his ability to pay the same, to determine a reasonable arrearage payment schedule, and to enter an income withholding order within the limits of Indiana law. ${ }^{422}$

4. Arrearage Payments after the Death of the Recipient Spouse.-In Roop

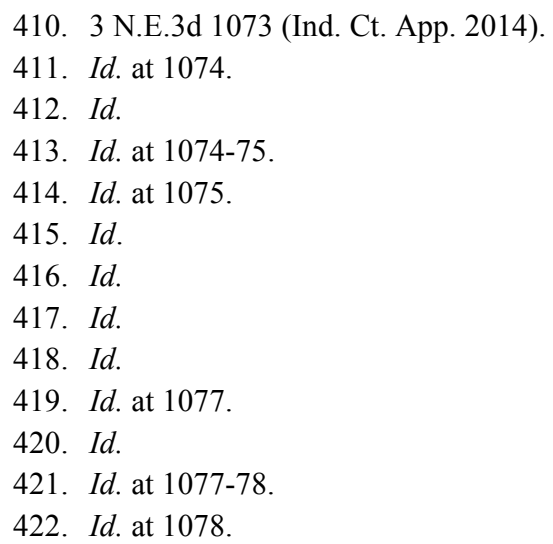


v. Buchanan ${ }^{423}$ the payor spouse outlived the recipient spouse and the trial court ordered the payor spouse to pay the outstanding child support arrearage to the parties' adult child. ${ }^{424}$ The parties dissolved their marriage, which produced two children, in $1994 .{ }^{425}$ Payor spouse accrued an arrearage over time in the amount of $\$ 22,000$ and commencing in 2003 , made regular payments reducing the arrearage to $\$ 9400$ at the time of recipient spouse's death in December 2012. ${ }^{426}$ Upon the death of recipient spouse, payor spouse contacted the trial court and requested relief from paying the remaining arrearage. ${ }^{427}$

After a hearing on payor spouse's requests, the trial court ordered the existing arrearage first be paid to the parties' oldest daughter as reimbursement for funeral expenses incurred on behalf of recipient spouse, in the amount of $\$ 10$ per week until paid off, and thereafter to be paid in equal amounts to the adult children. ${ }^{428}$ In March 2013, the trial court conducted another hearing as funeral expenses had not been paid by the parties' oldest daughter and daughter was holding uncashed support checks. ${ }^{429}$ The trial court then reaffirmed its judgment, directing daughter to pay the proceeds of the support checks to the funeral home, or direct the payments, once a judgment was incurred on the outstanding sums owed, to the funeral home. ${ }^{430}$ The payor spouse then appealed. ${ }^{431}$

The court of appeals outlined that once child support accrues for the child's benefit, the trial court lacks the authority to reduce, annul, or vacate the support order retroactively. ${ }^{432}$ The court then described several cases, which may help guide practitioners who encounter a similar fact pattern, including Lizak $v$. Schultz, ${ }^{433}$ In re Hambright, ${ }^{434}$ Hicks v. Smith ${ }^{435}$ and Thacker v. Thacker. ${ }^{436}$ Applying the principles of these cases, the court held that payor spouse was obligated to pay the total amount of the arrearage even after recipient spouse's death as the arrearage constituted child support sums advanced by the recipient spouse. ${ }^{437}$ Typically, these sums are collected by the personal representative of the estate; however, as no estate had been opened, the court found that the trial court appropriately ordered payor spouse to pay recipient spouse's funeral costs

423. 999 N.E.2d 457 (Ind. Ct. App. 2013).

424. Id. at 458-59.

425. Id. at 458 .

426. Id. at 459 .

427. Id.

428. $I d$.

429. Id.

430. Id. at 460 .

431. Id.

432. Id. (citing Whited v. Whited, 859 N.E.2d 657, 661 (Ind. 2007); In re Hambright, 762 N.E.2d 98, 101 (Ind. 2002)).

433. 496 N.E.2d 40 (Ind. 1986).

434. 762 N.E.2d 98 (Ind. 2002).

435. 919 N.E.2d 1169 (Ind. Ct. App.), trans. denied, 929 N.E.2d 791 (Ind. 2010).

436. 710 N.E.2d 942 (Ind. Ct. App. 1999).

437. Roop v. Buchanan, 999 N.E.2d 457, 460-62 (Ind. Ct. App. 2013). 
as these outstanding sums were owed because recipient spouse was unable to save for funeral expenses due to the failure of the payor spouse to provide adequate support for the children. ${ }^{438}$

The trial court's decision was affirmed, in part, as to the reimbursement for funeral expenses, which totaled $\$ 8026 .{ }^{439}$ As the arrearage totaled $\$ 9,464.27$, however, the court also reversed that part of the trial court's order requiring the remaining arrearage after funeral expenses be paid to the parties' children directly, finding this violated the principles outlined in Lizak, that the arrearage is a debt owed to the custodial parent as trustee of the child. ${ }^{440}$

\section{ADOPTION AND GUARDIANSHIP}

During the survey period, the appellate courts issued a variety of opinions regarding the interplay of jurisdiction between counties and courts, and provided substantial analysis of notice and consent requirements that accompany adoption and guardianship matters.

\section{A. Jurisdiction}

Two decisions were handed down from the appellate courts which provide instruction to practitioners on the issues of jurisdiction and venue involving adoption, paternity, and guardianship matters, particularly when there are multiple types of causes relating to the same child.

In re the Paternity of B.C. ${ }^{441}$ dealt with the interplay of the jurisdiction of probate courts and juvenile courts when adoptions or guardianships and paternity determinations are at issue. ${ }^{442}$ Child was born in August 2010 without a father listed on the birth certificate. ${ }^{443}$ In March 2012, the child's maternal grandfather and his significant other filed for appointment as guardians of the child in Marion County Superior Court, Probate Division, ("Marion County"), stating in their petition that father was unknown and mother consented to temporary guardianship. ${ }^{444}$ Guardians' petition was granted in July 2012. ${ }^{445}$ In December 2012, putative father filed a Verified Petition to Establish Paternity, Custody, Support, and Parenting Time in the Montgomery Circuit Court ("Montgomery County"), which case was pending on the juvenile docket. ${ }^{446}$ Montgomery County approved an agreed entry between father and mother, which established father's paternity of the child. ${ }^{447}$ Father then filed a motion to dismiss the

\footnotetext{
438. Id. at 462 .

439. Id. at 462-63.

440. Id.

441. 9 N.E.3d 745 (Ind. Ct. App. 2014).

442. See id. at 750-55.

443. Id. at 747 .

444. Id.

445. $I d$.

446. Id.

447. Id.
} 
guardianship in Marion County, and guardians subsequently filed a Motion to Intervene in the Montgomery County paternity proceedings, requesting DNA testing, and also requesting the agreed paternity order be set aside. ${ }^{448}$ Montgomery County granted guardians' motion to intervene but denied their motion to set aside paternity and for DNA testing. ${ }^{449}$

On May 20, 2013, guardians filed their Petition for Adoption in Marion County, and father, in June 2013, filed his petition to establish custody in Montgomery County. ${ }^{450}$ Guardians then requested father's petition be consolidated and transferred to Marion County under the guardianship action. ${ }^{451}$

In June 2013, father objected to the guardians' motion to consolidate and Montgomery County held a hearing on the guardians' motion which included testimony that an adoption proceeding was pending in Marion County. ${ }^{452}$ Montgomery County ultimately issued an order on physical and legal custody of the child, as well as parenting time for father and mother, upon her release from incarceration. ${ }^{453}$ Guardians filed a motion to correct error, which was denied. ${ }^{454}$

Then, in July, father filed his objection to the adoption in Marion County and a motion to dismiss. ${ }^{455}$ Marion County granted father's motions and dismissed the guardianship and adoption actions. ${ }^{456}$ Guardians responded by filing a motion to correct error, which was later denied, and guardians appealed the Montgomery County order as well as the Marion County orders on dismissal. ${ }^{457}$

The court of appeals reviewed the Indiana Code provisions regarding original and concurrent jurisdiction for civil cases, which governed guardians' guardianship action in Marion County. ${ }^{458}$ Because Marion County had proper jurisdiction over the original guardianship action, the question then turned to whether Montgomery County had jurisdiction to adjudicate issues already pending in Marion County when it issued its order establishing paternity. ${ }^{459}$ Two courts cannot deal with the same subject matter at the same time, ${ }^{460}$ and the establishment of paternity is governed specifically by Indiana Code section 3130-1-1(3), stating a juvenile court has original jurisdiction in proceedings concerning paternity. ${ }^{461}$ For this reason, Montgomery County properly issued its

448. Id.
449. Id.
450. Id.
451. Id. at 748.
452. Id. at $748-49$.
453. Id. at 749.
454. Id.
455. Id.
456. Id.
457. Id. at $749-50$.
458. Id at $750-52$.
459. Id. at 753.
460. In re Paternity of Fox, 514 N.E.2d 638, 641 (Ind. Ct. App. 1987).
461. In re B.C., 9 N.E.3d 752 (quoting IND. CoDE $\S 31-30-1-1(3)$ (2012)). 
order establishing paternity of father. ${ }^{462}$

The next step in adjudication of the appropriate court is more complicated as all three pending matters, which include guardianship, adoption, and paternity, relate to custody. ${ }^{463}$ In making this determination, the language of Indiana Code section 31-19-2-14(a) governs, stating that if an adoption petition and paternity petition are pending at the same time for the same child, the court with jurisdiction over the adoption has exclusive jurisdiction and the paternity proceeding must be consolidated. ${ }^{464}$ While father argued guardians waived this issue, the court of appeals disagreed, finding that guardians did request transfer to Marion County, albeit under the guardianship cause. ${ }^{465}$ Guardians' testimony about the pending adoption in Marion County further served as notice to Montgomery County of the pending adoption and need to transfer the same. ${ }^{466}$

Father then argued that Indiana Code section 31-19-2-14(a) does not apply because the paternity petition was filed before the adoption petition; however, the court of appeals clarified that the language of the code does not limit its applicability to prior-filed paternity actions, and instead explained that the paternity petition is simply consolidated but remains alive under the adoption cause. ${ }^{467}$ The court found the trial courts in Montgomery County and Marion County erred, and accordingly reversed the decisions in both courts with instructions to comply with the provisions of Indiana Code sections 31-19 and $29-3 .{ }^{468}$

A second jurisdictional question arose in In re the Adoption of L.T., ${ }^{469}$ when maternal grandparents filed a petition for guardianship in Hamilton County Superior Court ("Hamilton County") after mother passed away in $2012 .{ }^{470}$ In this case, child was born in 2010 and Marion County Circuit Court, Paternity Division ("Marion County, Paternity Division") initially established father as biological father, awarded custody to mother, and ordered father to pay support. ${ }^{471}$ Upon mother's death, maternal grandparents introduced their petition for guardianship, which included a waiver of notice and consent to guardianship bearing father's name and notarized signature. ${ }^{472}$ Father then filed a motion to set aside and paternal grandparents ("interveners") filed a petition to transfer the Hamilton County guardianship proceedings to Marion County, Paternity Division; Marion County, Paternity Division entered an order to transfer and consolidate in Marion County and Hamilton County entered an order of

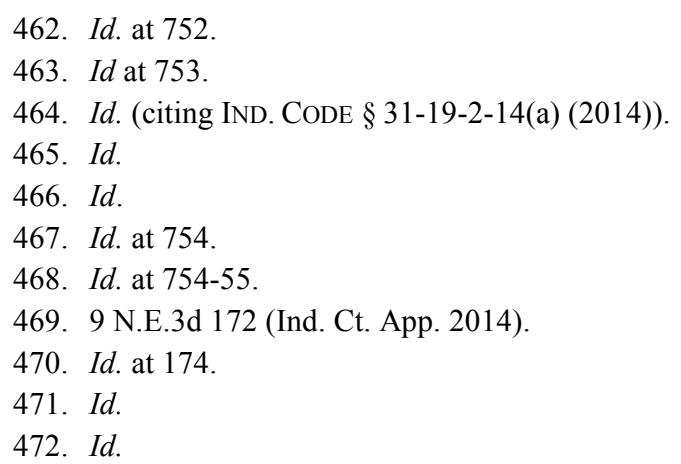


transfer. ${ }^{473}$ In February 2013, grandparents filed a petition to adopt the child in Marion County Superior Court, Probate Division ("Marion County, Probate Division") and in March 2013, Marion County, Paternity Division transferred the paternity proceedings to Marion County, Probate Division. ${ }^{474}$ Father, in response, filed a motion contesting the adoption and attached a certified copy of his support payment history. ${ }^{475}$ Marion County, Probate Division, after a hearing on the issue of Hamilton County's jurisdiction over the guardianship proceedings, issued an order dismissing the guardianship, stating that Hamilton County lacked jurisdiction to enter guardianship orders. ${ }^{476}$ The trial court's order was stayed pending grandparents' appeal. ${ }^{477}$

In this case, the court of appeals considered the subject matter jurisdiction and personal jurisdiction of Hamilton County. ${ }^{478}$ The court of appeals clarified that, while Hamilton County had statutory authority to hear the guardianship matter, it did not have proper venue as the child was not a Hamilton County resident, which made Marion County the proper venue to hear a guardianship action over the child. ${ }^{479}$ However, the court of appeals noted that father was not litigating custody in Marion County when the authority of Hamilton County was invoked and rather, he signed a consent to child's guardianship which relinquished his right to physical custody of the child. ${ }^{480}$ Therefore, Hamilton County had subject matter jurisdiction to conduct the guardianship action and properly transferred the matter to Marion County, Paternity Division, upon notification of improper venue. ${ }^{481}$ Once consolidated, however, Marion County, Probate Division, was required to complete the pending proceeding. ${ }^{482}$

Guardians also contested that Marion County, Probate Division, erred in ordering physical custody to father without a hearing adjudicating the child's best interests. ${ }^{483}$ Guardians also prevailed on this issue, as Marion County, Probate Division was required to make a determination on child's best interests and changed circumstances as father relinquished his right to custody immediately at the time of mother's death. ${ }^{484}$ While father contested that Indiana Code section 29-3-3-3 provides that upon the death of one parent, the surviving parent has the right to custody of the minor child, the court of appeals articulated that Indiana Code section 29-3-3-3 does not apply in light of father's signed consent which

\footnotetext{
473. $I d$.

474. $I d$.

475. Id.

476. Id. at $174-75$.

477. Id. at 175.

478. Id.

479. Id. at 176 .

480. Id. at 177 .

481. Id.

482. Id.

483. $I d$.

484. Id. at 179.
} 
acknowledged the child needed guardians. ${ }^{485}$ Accordingly, the court of appeals reversed the trial court's decision and instructed Marion County, Probate Division to conduct a hearing on the best interests of the child. ${ }^{486}$

\section{B. Notice and Consent}

For cases involving adoption and guardianship, the most frequent issues on appeal deal with the requirements for notice and consent. A majority of the cases herein address these statutory provisions; further, during the survey period, an important opinion was issued with respect to the filing of an untimely notice of appeal.

1. Putative Fathers Must Timely Register on the Putative Father Registry to Be Entitled to Notice.-In the case of In re Adoption and Paternity of K.G.B. ${ }^{487}$ child was born out of wedlock to mother in August 2012, and one year after the child's birth, mother consented to child's adoption by maternal grandfather. ${ }^{488}$ At the time of the adoption, the parties searched the Indiana Putative Father Registry ("Registry"), which did not reveal any putative fathers or paternity actions. ${ }^{489}$ Over one and one-half months after child's adoption, putative father filed a petition requesting establishment of paternity and presented a motion to contest child's adoption, in which putative father acknowledged his failure to timely register with the Registry. ${ }^{490}$ Mother filed a motion to dismiss putative father's paternity petition, and grandfather filed a request to strike putative father's motion contesting adoption. ${ }^{491}$

In December 2013, the trial court conducted a hearing on putative father's pending motions and ultimately granted, in January 2014, mother's motion to dismiss and grandfather's motion to strike putative father's motion contesting adoption. ${ }^{492}$ Putative father filed an amended paternity action, as next friend of child, the day after the trial court issued its orders and later filed a motion to correct error, which was denied by the trial court. ${ }^{493}$ Putative father appealed. ${ }^{494}$

The court of appeals looked at the clear language of Indiana Code section 3119-5-4, which states that a putative father who registers with the Registry in accordance with Indiana Code chapter 31-19-5 is entitled to notice of the child's adoption. ${ }^{495}$ Pursuant to Indiana Code section 31-19-5-12(a), putative fathers must register "thirty (30) days after the child's birth; or . . the earlier of the date

485. Id. at 178-79 (citing IND. CODE $§ ~ 29-3-3-3 ~(2015)$ ).

486. Id. at 179 .

487. 18 N.E.3d 292 (Ind. Ct. App. 2014).

488. Id. at 295.

489. Id.

490. Id. at $295-96$.

491. Id. at 296.

492. Id.

493. Id.

494. Id.

495. Id. at 297. 
of the filing of a petition for the: (A) child's adoption; or (B) termination of the parent-child relationship between the child and the child's mother; whichever occurs later." to notice was waived and his consent to the adoption was irrevocably implied. ${ }^{497}$

Putative father additionally argued that he was entitled to notice because circumstantial evidence existed that mother disclosed his name or address to an attorney ${ }^{498}$ and that the statutory scheme relating to the Registry is an unconstitutional violation of his due process rights; ${ }^{499}$ however, the court of appeals disagreed with putative father's arguments. ${ }^{500}$ The court also analyzed putative father's final argument that he did not waive his right to establish paternity by amending his filing after the trial court's order, concluding that putative father was not eligible to establish paternity as next friend of child based on the clear language of Indiana Code section 31-14-5-9.501

The trial court's decision was affirmed by the court of appeals as putative father was not entitled to notice of the adoption due to his failure to register as a putative father, and the court concluded that this failure constituted irrevocable implied consent to the adoption. ${ }^{502}$ Further, due to this consent, he was barred from establishing paternity under his own petition or as next friend. ${ }^{503}$ Accordingly, the court remanded the matter for further proceedings on child's adoption. ${ }^{504}$

2. Notice to Parents and Non-Parties in Adoption Matters. - In re Adoption of J.L.J. ${ }^{505}$ also analyzes the notice and consent requirements for parents and nonparties who may qualify as primary caregivers. ${ }^{506}$ This case involves the adoption of twins who, for the first year after their births in 2011, resided in many houses, both of relatives and non-relatives in Michigan and Indiana. ${ }^{507}$ While father spent time with the twins when in the company of mother or grandmother, he did not play a significant role in their care or support. ${ }^{508}$ Father's paternity was established while he was in jail in 2011, and a weekly child support obligation and arrearage payment order was entered. ${ }^{509}$

In summer 2011, upon hearing of the likelihood of father's extended incarceration, mother sought out someone to care for the twins in a more

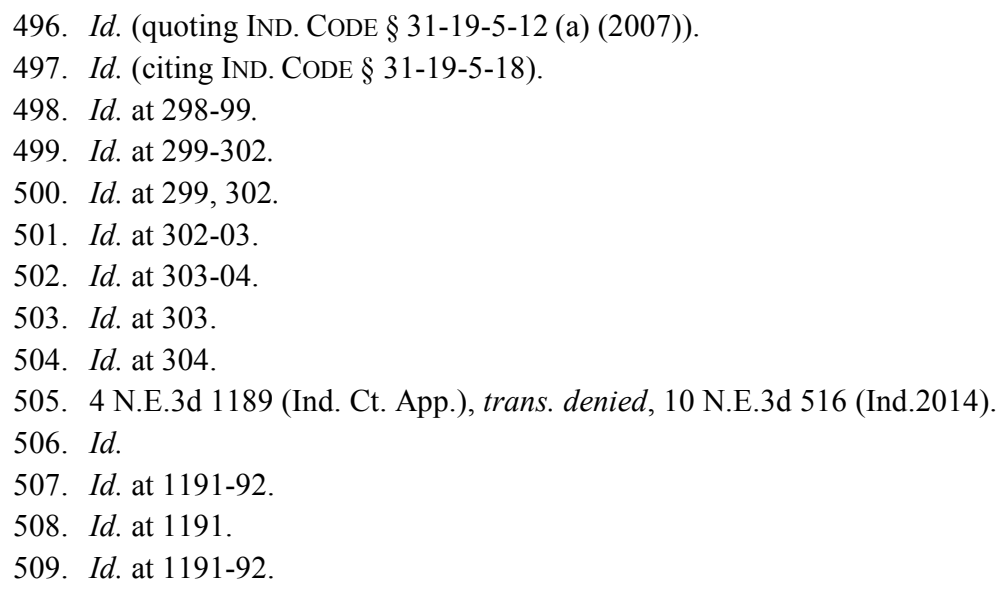


permanent arrangement. ${ }^{510}$ Mother then took the twins from grandmother's home and requested that grandmother provide her with the twins' birth certificates and social security cards by mail. ${ }^{511}$ By September 2011, the twins resided in Bloomington, Indiana, with guardian, with mother's consent. ${ }^{512}$ At the end of September, guardian initiated her petitions for guardianship with the trial court and also filed petitions to adopt the twins. ${ }^{513}$ Guardian served notice on father; however, father did not appear at the hearing and guardian was appointed pending the adoption finalization. ${ }^{514}$

Upon father's release from jail in December 2011, he filed a letter with the court requesting an extension to contest the adoption and finally filed his motion to contest in February 2012. ${ }^{515}$ In March 2012, grandmother filed her motion to intervene and requested that she adopt the twins. ${ }^{516}$ The trial court granted grandmother's motion as she stated that she was the twins' primary caregiver and grandmother. ${ }^{517}$ Grandmother then filed subsequent petitions requesting guardian be removed and she be appointed as the twins' guardian. ${ }^{518}$ Evidence was heard from guardian, grandmother, and father regarding their pending motions. ${ }^{519}$ The trial court concluded that father's consent was not required due to his failure to provide support for over one year, denied grandmother's petitions regarding guardian's removal and grandmother's petitions for adoption, and found that it was in the twins' best interest to be adopted by guardian. ${ }^{520}$ Grandmother and father subsequently appealed. ${ }^{521}$

The court of appeals held that despite father's incarceration, he had both the obligation and ability to provide support to the twins but failed to do so. ${ }^{522}$ Father presented conflicting testimony as he acknowledged his obligation to provide for the twins, and despite his failure to ever pay support, and he demonstrated an ability to provide for himself as he found funds for discretionary travel and cigarettes, while still not contributing to the twins' support. ${ }^{523}$ Thus, there was sufficient evidence supporting the trial court's finding that father's consent was not necessary. ${ }^{524}$

The court of appeals then analyzed grandmother's arguments, again finding

510. Id. at 1192.
511. Id.
512. Id.
513. Id.
514. Id.
515. Id.
516. Id. at 1193.
517. Id.
518. Id.
519. Id.
520. Id.
521. Id.
522. Id. at $1194-95$.
523. Id. at $1195-96$.
524. Id. at 1197.


inconsistencies with her testimony that led to the denial of her claims. ${ }^{525}$ Grandmother failed to present sufficient evidence to establish that she was a principal caregiver warranting notice of the petition for guardianship, nor did she establish that guardian should have known she was a potential primary caregiver as mother ultimately tendered the twins to guardian. ${ }^{526}$ Grandmother also alleged that the trial court failed to abide by the provisions of the Interstate Compact on the Placement of Children; however, the court of appeals found that this Compact did not apply as mother, the twins' parent, took the children from Michigan to Indiana and left the twins with a non-agency guardian. ${ }^{527}$

In her final argument, grandmother proposed the trial court abused its discretion when it denied her petitions to remove guardian and to adopt the twins. ${ }^{528}$ The court reiterated the numerous factors cited by the trial court which lead to the trial court's decision and ultimately, the court of appeals' affirmation that it was in the twins' best interest to be adopted by guardian. ${ }^{529}$ One of grandmother's major contentions was that the trial court ignored the parents' wishes, as they were suddenly agreeable to grandmother becoming the twins' legally adoptive mother, and failed to consider the weight and importance of grandmother's familial connection. ${ }^{530}$ Citing In re Adoption of Childers,${ }^{531}$ the court reiterated that trial courts have complete discretion to consider some factors over others, including a blood relationship, when determining the best interests of the children in an adoption proceeding. ${ }^{532}$ As the court did not find an abuse of discretion in the trial court's order and would not reweigh the evidence presented, the trial court's order was affirmed. ${ }^{533}$

3. Consent and Justifiable Cause for Failure to Communicate with Children.-The court of appeals' decision in D.D. v. DP. ${ }^{534}$ sent a warning to parents who seek to thwart a relationship between the children and the noncustodial parent in an effort to satisfy the provisions of Indiana Code section 31-19-9-8(a)(2)(A), which states that a parent's consent to adoption is not required when that parent fails to communicate with the child for over one year and is able to do so. ${ }^{535}$ Mother and father divorced in 2004 when the children were only twenty-three months and four months old. ${ }^{536}$ Father was also ordered

525. Id. at 1197-200.

526. Id. at 1198-99.

527. Id. at 1199 (citing IND. CODE § 31-28-4-1, art. III (a)-(c) (2006)).

528. $I d$.

529. Id. at $1199-200$.

530. Id. at 1200 .

531. 441 N.E.2d 976, 980 (Ind. Ct. App. 1982).

532. In re Adoption of J.L.J., 4 N.E.3d at 1200.

533. Id.

534. 8 N.E.3d 217 (Ind. Ct. App. 2014).

535. Id. at 221 (noting mother's actions hampered and thwarted father's attempts to communicate with the children, ultimately reducing father's efforts to reestablish contact with the children).

536. Id. at 218 . 
to pay $\$ 502$ per week in child support. ${ }^{537}$ After the dissolution, father saw the children a few times but was required to relocate to Washington, D.C., for work. ${ }^{538}$ Father attempted to reach mother on multiple occasions by phone and email regarding a reestablishment of his relationship with the children; however, mother either rarely returned emails or discouraged father's interaction with the children, indicating it would be traumatic for them. ${ }^{539}$

Mother remarried in 2007 and stepfather filed a petition to adopt the children in November 2009 in the Hendricks County Superior Court, the county of residence of mother, stepfather, and the children. ${ }^{540}$ The petition was never served on father, no summons was issued, and a hearing was held without notice to father. ${ }^{541}$ The adoption petition was granted without father's knowledge or consent and a few months later, mother moved to terminate father's support withholding order. ${ }^{542}$

Upon receiving this notice regarding support, father filed an objection to mother's motion and moved to establish parenting time in Marion County Superior Court, where the parties' divorce had been granted. ${ }^{543}$ In March 2010, Hendricks County vacated the adoption decree for lack of proper service on father; however, stepfather's petition remained pending. ${ }^{54}$ Upon father's request, the Hendricks County adoption was transferred to Marion County. ${ }^{545}$ After a contested hearing in Marion County, the trial court ruled that father's consent to the adoption was required, as stepfather had not proven father failed to communicate with the children for more than one year without justifiable cause. ${ }^{546}$ Stepfather appealed. ${ }^{547}$

On appeal, stepfather argued that father failed to communicate with the children for over five years, four years longer than required by Indiana Code. ${ }^{548}$ The court of appeals critically looked at the ages of the children when the parties dissolved their marriage, father's efforts to communicate with mother, and mother's responses to father's efforts. ${ }^{549}$ The trial court found that mother did not respond to father's emails or if she did respond, she only appeared interested in terminating father's parental rights or attempting to convince father that it was in the children's best interests to be adopted by stepfather. ${ }^{550}$ In light of the

537. $I d$.

538. Id.

539. Id. at 218-19.

540. Id.

541. Id. at 219.

542. Id.

543. $I d$.

544. Id.

545. Id. at 219-20.

546. Id. at 220.

547. Id.

548. Id.

549. Id. at 221.

550. Id. at 221-22. 
evidence on record demonstrating mother's actions, the court affirmed the trial court's finding that father demonstrated justifiable cause for not initiating contact with the children, namely due to mother's discouragement and dissuasion to father regarding contact with the children. ${ }^{551}$

4. Timeliness of Requesting an Appeal.-In re Adoption of O.R. ${ }^{552}$ is an Indiana Supreme Court decision in which father appealed an order granting adoption by adoptive parents by mailing a letter to the trial court clerk which requested appointment of appellate counsel "for the purpose of appealing the decision rendered." 553 The discussion of the case focused on the timeliness of father's filing his Notice of Appeal and whether or not his right to appeal had been forfeited and thereafter decided father's appeal on the merits. ${ }^{554}$

O.R. was born out of wedlock in August 2006 and was placed with adoptive parents when she was four months old. ${ }^{555}$ Adoptive parents exercised custodial care of O.R. for the majority of her life and adoptive parents filed their petition to adopt her in 2012. ${ }^{556}$ Biological mother consented to the adoption; but father, who was serving a seven and one-half year sentence in the Indiana Department of Correction, did not consent. ${ }^{557}$ Father and adoptive parents appeared for a trial and thereafter, the trial court granted adoptive parents' petition and found that father's consent was not required because of father's failure to communicate with the child and to provide support for her. ${ }^{558}$

Father wrote a letter to the court four days before the deadline to file his Notice of Appeal and in his letter requested new counsel as he wanted to appeal the trial court's decision. ${ }^{559}$ Father's trial counsel did not file a Notice of Appeal but did withdraw nine days after a Notice of Appeal was due. ${ }^{560}$ Twenty-three days after the deadline to appeal, the trial court granted father's request for appellate counsel and father's petition to accept an Amended Notice of Appeal was filed fifteen days after the appointment of his counsel, or thirty-eight days after his Notice of Appeal was due. ${ }^{561}$ Father's counsel argued that father's appeal should be deemed timely filed as his pro se letter substantially complied with the appellate rules. ${ }^{562}$ The motions panel of the court of appeals granted father's petition and accepted his Amended Notice of Appeal. ${ }^{563}$ After the case was fully briefed, the court of appeals, sua sponte, dismissed father's appeal,

551. Id. at 222 .

552. 16 N.E.3d 965 (Ind. 2014).

553. $I d$. at 968 .

554. Id. at $968-75$.

555. Id. at 968 .

556. $I d$.

557. Id.

558. Id.

559. Id.

560. Id.

561. Id.

562. Id.

563. Id 
stating that it lacked subject matter jurisdiction over the appeal as father's Notice of Appeal was not timely. ${ }^{564}$ Father petitioned for transfer to the Indiana Supreme Court to address the dismissal and the merit of his claims. ${ }^{565}$

The court outlined the challenges in differentiating jurisdictional issues from procedural errors ${ }^{566}$ or mischaracterized claim-processing rules ${ }^{567}$ Clarifying the appellate rules, the supreme court explained that a party loses his or her right to appeal for failing to timely file a Notice of Appeal but this forfeiture does not signify the appellate courts are deprived of the authority to entertain the merits of an appeal. ${ }^{568}$ Therefore, the timely filing of a Notice of Appeal is not a jurisdictional issue, but rather serves as a prerequisite for the initiation of an appeal. ${ }^{569}$

The court noted that, "the right to appeal having been forfeited, the question is whether there are extraordinarily compelling reasons why this forfeited right should be restored." ${ }^{570}$ In its rationale for reversing the court of appeals" dismissal, the court reminded practitioners that the appellate rules are the means of achieving the "ultimate end of orderly and speedy justice." 571 In determining whether to entertain father's appeal, the court considered the following facts to amount to extraordinary and compelling reasons as to why his forfeited appeal should be heard: father's timeliness in seeking appellate counsel and making his intentions to appeal known with the trial clerk, as well as the importance of father's Fourteenth Amendment right to parent as a fundamental liberty interest. ${ }^{572}$ The Indiana Supreme Court held that father attempted to perfect a timely appeal which related to his constitutional right to a parent-child relationship and therefore deserved a review on its merits. ${ }^{573}$

Therefore, although father had forfeited his right to appeal, the court found extraordinarily compelling reasons why his forfeited right should be restored and thereafter reviewed father's claims on the merits. ${ }^{574}$ Upon review, father was required to show a clearly erroneous judgment where no evidence supports the findings. ${ }^{575}$ The court reviewed the statutory applicability of father's consent, and determined that his consent was not required, as father failed to communicate with daughter but for one phone call in 2011 when child was five years old. ${ }^{576}$

564. $I d$.

565. Id.

566. Id. at 970 (citing K.S. v. State, 849 N.E.2d 4538, 541 (Ind. 2006)).

567. Id. (citing Reed Elsevier, Inc. v. Muchnick, 559 U.S. 154, 161 (2010)).

568. Id. at 971 (citing Packard v. Shoopman, 852 N.E.2d 927 (Ind. 2006)).

569. Id.

570. $I d$.

571. Id. at 972 (citing In re Adoption of T.L., 4 N.E.3d 658, 661 n.2 (Ind. 2014)).

572. Id. (citing Troxel v. Granville, 530 U.S. 57, 65 (2000); Pierce v. Soc'y of Sisters, 268

U.S. 510, 534-35 (1925)).

573. Id.

574. Id.

575. Id. at 973 (citing In re Paternity of K.I., 903 N.E.2d 453, 457 (Ind. 2009)).

576. Id. at $973-74$. 
Father also never sent correspondence to O.R. during his incarceration. ${ }^{577}$ Father argued that he had justifiable cause for his failure to communicate with O.R., as adoptive parents declined to bring O.R. to visit him in prison when he voluntarily granted adoptive parents guardianship of O.R. ${ }^{578}$ The record, however, contradicted father's testimony as during this time, O.R. was the subject of a protective order against father, and upon expiration of the protective order, father never requested visitation thereafter or sent letters ${ }^{579}$ Father's final unsuccessful argument claimed he did not have adoptive parents' address; however, evidence supported that this excuse was not probative, as adoptive parents were represented by counsel and father could have initiated contact through their representative.$^{580}$ As a result, the court found the record clear and convincing to show that father's consent was not necessary, and that the trial court appropriately adjudicated that O.R.'s adoption by adoptive parents was in her best interests. ${ }^{581}$

Given this opinion, the authors would offer the following as a practice tip: if a party petitions to file an untimely Notice of Appeal, the party is going to have to allege extraordinarily compelling reasons for the court of appeals to consider it, and those reasons might include the necessity of showing some diligence in trying to file the untimely notice as soon as possible. Essentially, filing an untimely Notice of Appeal equates to a party's right to the appellate court's consideration of the appeal forfeited, and if a party can show extraordinarily compelling reasons, the court of appeals will entertain said appeal at its discretion. To be clear: the appellate court is not required to entertain any appeal that is not timely filed, but can, when presented with extraordinarily compelling reasons; a timely Notice of Appeal is no longer jurisdictional, but the appellate court's consideration of an untimely appeal is discretionary. It is not open season on filing a notice of appeal whenever a party would like; the presumption is still going to be that a party has forfeited his or her right if the Notice of Appeal is filed past thirty days.

\section{CONCLUSION}

Family law decisions rendered by the appellate courts of Indiana and the federal appellate court case addressed herein during the survey period made great headway in developing and clarifying the rights of children, parents, de facto custodians, and grandparents in cases involving dissolution of marriage issues, the rights of same-sex couples, custody, grandparent visitation matters, child support calculation procedures, and adoption cases.

577. Id. at 974 .

578. Id.

579. Id.

580. Id.

581. Id. at $974-75$. 
